\title{
Downhole variation of lithium and oxygen isotopic compositions of oceanic crust at East Pacific Rise, ODP Site 1256
}

\section{Y. Gao}

Department of Earth and Atmospheric Sciences, University of Houston, Houston, Texas 77204, USA (ygao@mail.uh.edu)

\section{F. Vils}

Department of Earth Sciences, University of Bristol, Bristol BS8 1RJ, UK

\section{K. M. Cooper}

Department of Geology, University of California, Davis, California 95616, USA

\section{N. Banerjee}

Department of Earth Sciences, University of Western Ontario, London, Ontario N6A 3K7, Canada

\section{Harris}

National Oceanography Centre Southampton, University of Southampton, Southampton SO14 3ZH, $U K$

\section{J. Hoefs}

Geowissenschaftliches Zentrum, University of Goettingen, Goettingen DE-37077, Germany

\section{A. H. Teagle}

National Oceanography Centre Southampton, University of Southampton, Southampton SO14 3ZH, $U K$

\section{J. F. Casey}

Department of Earth and Atmospheric Sciences, University of Houston, Houston, Texas 77204, USA

\section{T. Elliott}

Department of Earth Sciences, University of Bristol, Bristol BS8 1RJ, UK

\section{Laverne}

Laboratoire de Pétrologie Magmatique, Université Paul Cézanne Aix-Marseille III, FR-13397 Marseille, France

\section{J. C. Alt}

Department of Earth and Environmental Sciences, University of Michigan, Ann Arbor, Michigan 48109, USA

\section{K. Muehlenbachs}

Department of Earth and Atmospheric Sciences, University of Alberta, Edmonton, Alberta 6G 2E3, Canada 
[1] Bulk rock lithium and oxygen isotope compositions from ODP Site 1256 were analyzed to investigate the seawater circulation in the upper oceanic crust formed at the East Pacific Rise (EPR). The upper extrusive basalts have $\delta^{18} \mathrm{O}$ values from $+6.1 \%$ to $+9.2 \%$, reflecting alteration of oceanic crust by seawater at low temperatures $\left(<200-250^{\circ} \mathrm{C}\right)$. Bulk rocks from the sheeted dike complex and plutonic section have overall lower $\delta^{18} \mathrm{O}$ values $\left(+3.0 \% 0^{-}+5.5 \%\right.$ ). In the sheeted dike complex bulk rock $\delta^{18} \mathrm{O}$ values gradually decrease with depth, and then increase toward the fresh MORB $\delta^{18} \mathrm{O}$ value after reaching a minimum of $+3.0 \%$ at $\sim 1350 \mathrm{~m}$ below seafloor (mbsf). The entire sampled crust is dominated by rocks with low lithium contents relative to fresh MORBs except for a few localized Li enrichment. The upper volcanic zone is characterized by a spread of $\delta^{7} \mathrm{Li}$ from low to high values relative to average unaltered MORB values $\left(\delta^{7} \mathrm{Li}=+3.4 \pm 1.4 \%\right)$. The presence of rocks with low $\delta^{7} \mathrm{Li}$ values in the upper crust most likely indicates zones of upwelling of relatively hot $\left(\sim 200-250^{\circ} \mathrm{C}\right)$ hydrothermal fluids. In the sheeted dike complex, bulk rock $\delta^{7} \mathrm{Li}$ values show wide range of variation, but exhibit a general trend from enriched to depleted values at $\sim 1280 \mathrm{mbsf}$ and then return to that for fresh MORB within the upper tens of meters of the plutonic section at the bottom of the after reaching a minimum at $\sim 1350 \mathrm{mbsf}\left(\delta^{7} \mathrm{Li}=-1.6 \%\right)$. The downhole pattern of $\delta^{7} \mathrm{Li}$ principally reflects variations in water-rock ratio $(\mathrm{w} / \mathrm{r})$ together with a downhole increase of temperature. Seawater flow in the upper volcanic zone is likely to be channeled with generally small but variable $\mathrm{w} / \mathrm{r}$ ratios. The $\mathrm{w} / \mathrm{r}$ ratios increase rapidly with depth in the lower volcanic section into the sheeted dike complex indicating water dominated pervasive hydrothermal flow due to intensive upwelling of hydrothermal fluids.

Components: 14,500 words, 7 figures, 2 tables.

Keywords: hydrothermal systems; lithium isotope; ocean drilling; stable isotopes.

Index Terms: 1034 Geochemistry: Hydrothermal systems (0450, 3017, 3616, 4832, 8135, 8424); 1041 Geochemistry: Stable isotope geochemistry $(0454,4870) ; 3036$ Marine Geology and Geophysics: Ocean drilling.

Received 24 April 2012; Revised 29 August 2012; Accepted 5 September 2012; Published 5 October 2012.

Gao, Y., et al. (2012), Downhole variation of lithium and oxygen isotopic compositions of oceanic crust at East Pacific Rise, ODP Site 1256, Geochem. Geophys. Geosyst., 13, Q10001, doi:10.1029/2012GC004207.

\section{Introduction}

[2] Hydrothermal circulation at mid-ocean ridges through the permeable parts of the crust and upper mantle accounts for $34 \%$ of the predicted global oceanic heat flux and about $25 \%$ of the total heat flux of the Earth [Stein and Stein, 1994]. Owing to the differences in magma supply and the depth of axial magma lenses, hydrothermal circulation patterns at ridge axis differ with spreading rates [Phipps Morgan and Chen, 1993; German et al., 2004]. Seawater circulation at or near the mid ocean ridges (MORs) plays an important role in the modification of isotopic and chemical compositions of the oceanic crust and the oceans [e.g., Humphris, 1995; Alt and Teagle, 2000]. Our understanding of axial hydrothermal systems has been greatly advanced via both theoretical modeling [e.g., Phipps Morgan and Chen, 1993; Coumou et al., 2006; Fontaine and Wilcock, 2007] and studies of alteration patterns recorded in the oceanic crust [e.g., Alt et al., 1986, 2010; Gregory and Taylor, 1981;
Gillis et al., 2001; Heft et al., 2008]. However, some critical questions still need to be further assessed, such as the causes of spatial and temporal variability of axial hydrothermal systems and the discrepancy in the subsurface thermal structure between theoretical prediction and natural observations [Heft et al., 2008]. Oxygen isotopic compositions of altered samples are useful tracers of seawater-rock interactions and can provide information on the penetration depth of seawater and evolution of hydrothermal circulation [e.g., Gregory and Taylor, 1981; Alt et al., 1986; Alt and Teagle, 2000; Gao et al., 2006].

[3] Lithium isotopes are potentially the most powerful tracers of seawater-basalt interaction and crustmantle recycling [e.g., Chan et al., 1992, 2002; Elliott et al., 2004; Tomascak, 2004, and references therein]. Lithium is strongly mobilized by hydrous fluids [e.g., Brenan et al., 1998a; Moran et al., 1992; Seyfried et al., 1984,1998; Zack et al., 2003] and is moderately incompatible during mantle melting [Brenan et al., 1998b]. At low temperatures 
Li isotopes are subjected to a very large mass fractionations with up to $80 \%$ variation documented in terrestrial samples [Rudnick and Nakamura, 2004]. Similar to oxygen isotopes, the lithium isotopic compositions of altered samples are related to the water/rock ratio (w/r) and the fluid temperature [Bouman et al., 2004; Chan et al., 1992, 2002]. There is a large difference in $\mathrm{Li}$ content and isotopic composition between seawater $\left(0.2 \mu \mathrm{g} / \mathrm{g}\right.$ and $\delta^{7} \mathrm{Li}$ of $+31.1 \%$ [Chan et al., 1992]) and fresh N-MORBs $\left(6.7 \mu \mathrm{g} / \mathrm{g}\right.$ and $\delta^{7} \mathrm{Li}$ of $+3.4 \pm 1.4 \%$ [ Tomascak et al. 2008]). Therefore, the lithium isotopic composition of alteration products during seawater related alteration processes are highly sensitive to the water/rock ratios that define the amount of exchangeable $\mathrm{Li}$. The majority of $\mathrm{Li}$ incorporated into alteration minerals is from the destruction/dissolution of rock, unless the $\mathrm{w} / \mathrm{r}$ ratio is very high.

[4] Among the components entering subduction zones, lithium concentrations and $\delta^{7} \mathrm{Li}$ compositions of the lower oceanic crust (lowermost dikes and upper gabbros) remain the least characterized [Chan et al., 2002; Bouman, et al., 2004]. The lowermost dikes and upper gabbros have been identified as the root of axial high-temperature hydrothermal systems [e.g., Alt, 1995; Alt et al., 1996; Gillis et al., 2001]. However, such extensive alteration regions or zones of focused discharge near the dike/gabbro boundary are poorly documented within oceanic settings, and information from ophiolites may not be applicable to in situ ocean crust [Bickle and Teagle, 1992; Richardson et al., 1987; Schiffman and Smith, 1988].

[5] This paper presents paired Li and oxygen isotopic profiles derived from core samples through the upper oceanic crust from ODP Site 1256 that sampled from shallow extrusive levels to the uppermost gabbros below the sheeted dikes. We compare our results with the in situ lithium isotope profile [Chan et al., 2002] of upper oceanic crust sampled at ODP Hole 504B, which is located in 5.9-Ma-old crust about $200 \mathrm{~km}$ south of the Costa Rica Rift formed under an intermediate spreading rate $(68 \mathrm{~mm} / \mathrm{yr}$ [Alt et al., 1986]). We use these data to investigate the seawater-rock interaction in the upper oceanic crust and to constrain the penetration and circulation of seawater during the formation and evolution of oceanic crust at a superfast spreading ridge.

\section{Geological Setting and Methods}

[6] ODP Site $1256\left(6^{\circ} 44.2^{\prime} \mathrm{N}, 91^{\circ} 56.1^{\prime} \mathrm{W}\right)$ has been drilled into the Guatemala Basin on the Cocos plate. The oceanic crust at the drill site was formed $\sim 15$ m.y. ago on the eastern flank of the East Pacific Rise (Figure 1), during an episode of superfast spreading with rates up to $200 \mathrm{~mm} / \mathrm{yr}$ [Wilson, 1996; Wilson et al., 2003]. This location was initially within the equatorial high-productivity zone and endured high sedimentation rates $(>30 \mathrm{~m} / \mathrm{m} . \mathrm{y}$. [Farrell et al., 1995; Wilson et al., 2003]). The sediment thickness is $250 \mathrm{~m}$ at Site 1256 and is within the regional average $(200-300 \mathrm{~m}$ [Wilson et al., 2003]). Basement rocks were recovered from Hole 1256C and Hole 1256D, but the uppermost lavas were sampled only in Hole $1256 \mathrm{C}$ due to the setting of casing $19 \mathrm{~m}$ into basement in Hole 1256D [Wilson et al., 2003]. Pilot Hole 1256C cored $250.7 \mathrm{~m}$ of sediments and $88.5 \mathrm{~m}$ into the basement, that is composed of a $32 \mathrm{~m}$ thick lava pond with thin sheet flows above and below (Figure 2) [Wilson et al., 2003]. The main hole with the deepest penetration, Hole $1256 \mathrm{D}$, lays $\sim 30 \mathrm{~m}$ south of $1256 \mathrm{C}$, started coring at $276 \mathrm{~m}$ below seafloor (mbsf) within the uppermost basement and penetrated $1271 \mathrm{~m}$ into the oceanic basement completely through the volcanic and dike sections and into the uppermost plutonic rocks (Figure 2) [Wilson et al., 2006; Teagle et al., 2006, 2012].

\subsection{Lithostratigraphy of Hole 1256D}

[7] The oceanic crust sampled at Hole 1256D was portioned into six subdivisions based on the igneous stratigraphy developed from the recovered core (Figure 2) [Wilson et al., 2003; Teagle et al., 2006], which, from top to bottom, are the lava pond, inflated flows, sheet and massive flows, transition zone, sheeted dike complex, and plutonic complex [Teagle et al., 2006]. To facilitate the comparison with other profiles of the oceanic crust (e.g., ODP Site 504B and 896A [Chan et al., 2002]), we interpret the igneous lithostratigraphy relative to the following four subdivisions (Figure 2) based on the descriptions by shipboard scientists [Wilson et al., 2003; Teagle et al., 2006] and alteration processes defined by Alt et al. [2010]: 1) volcanic section; 2) transition zone; 3) sheeted dike complex; and 4) plutonic section.

[8] The volcanic section includes, from the top to the bottom, a lava pond ( 276-350.3 mbsf), inflated flows (350.3-533.9 mbsf) and sheet and massive flows (533.9-1004.2 mbsf). The sheeted and massive flows formed at the ridge axis, and are covered by thick ponded lavas and flows formed up to $\sim 3 \mathrm{~km}$ off axis that make up the upper $284 \mathrm{~m}$ of the volcanic section [Teagle et al., 2006; Tominaga et al., 2009; Tominaga and Umino, 2010]. The upper volcanic zone (down to $964 \mathrm{mbsf}$ ) has 


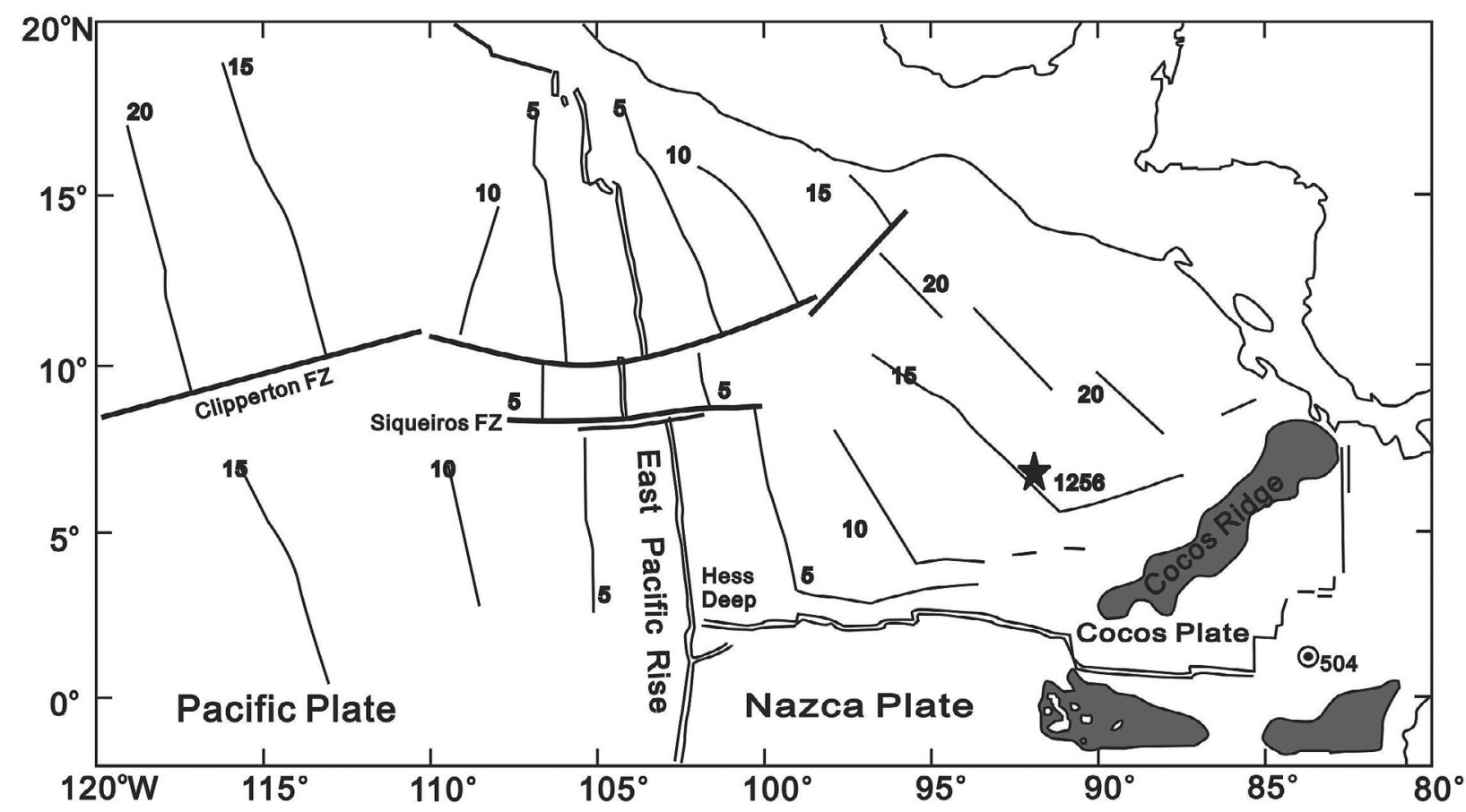

Figure 1. Location of Site 1256 in the eastern Pacific (modified after Teagle et al. [2006]). The location of DSDP/ ODP Hole 504B and isochrones (5 Ma intervals) are also shown.

reacted with seawater at low temperatures in reducing conditions as indicated by the presence of saponite \pm pyrite and the low abundance of red ironoxyhydroxide enriched alteration halos [Alt et al., 2010]. Uncommon oxidized alteration halos adjacent to iron oxyhydroxides and/or celadonite veins occur irregularly and are mostly related to fracture networks. The presence of pyrite-rich alteration halos, mixed-layer chlorite/smectite, and anhydrite in the lower volcanic section below 964 mbsf indicates elevated alteration temperatures $\left(100^{\circ} \mathrm{C}-200^{\circ} \mathrm{C}\right.$ [Teagle et al., 2006; Alt et al., 2010]). Overall, the volcanic section is slightly to moderately altered, but a highly altered $41 \mathrm{~cm}$ interval occurs at $648 \mathrm{mbsf}$ and has been interpreted as the presence of a narrow zone of focused fluid flow [Alt et al., 2010].

[9] The transition zone (1004.2-1060.9 mbsf) is marked by subvertical intrusive contacts and the appearance of greenschist faces minerals (including chlorite, albite, actinolite [Teagle et al., 2006]). Alteration in this zone is variable but commonly more intense than the overlying volcanic section. The alteration styles indicate that this section is a mixing zone between upwelling hydrothermal fluids and the downwelling seawater [Alt et al., 2010]. Similar to the transition zone in Hole 504B, the change from low temperature seawater alteration into higher-temperature hydrothermal alteration occurs over a narrow interval in this section [Alt et al., 1996, 2010].

[10] The sheeted dike complex (1060.9-1406.6 mbsf) contains rocks that are highly to completely altered [Teagle et al., 2006]. Alteration temperatures within the sheeted dikes increase downward from $\sim 250^{\circ} \mathrm{C}$ at the top to $\sim 400^{\circ} \mathrm{C}$ at the base [Teagle et al., 2006; Alt et al., 2010]. Subgreenschist to greenschist alteration occurs in the upper dikes and is indicated by the presence of chlorite, actinolite, albite, epidote, and titanite [Teagle et al., 2006]. The lowermost dikes (1348.3-1406.6 mbsf) display granoblastic textures that reflect strong contact metamorphism at or near magmatic temperatures [Koepke et al., 2008; France et al., 2009], superimposed on earlier hydrothermal alteration [Alt et al., 2010].

[11] The plutonic complex (1406.6-1507.1 mbsf) contains two gabbro bodies separated by a granoblastically recrystallized dike screen. Metamorphic conditions in this section are similar to those in the lower dikes [Alt et al., 2010] but the margins of the gabbro bodies are moderately altered with secondary minerals such as chlorite, amphibole, epidote, laumonite and prehnite present [Teagle et al., 2006]. 


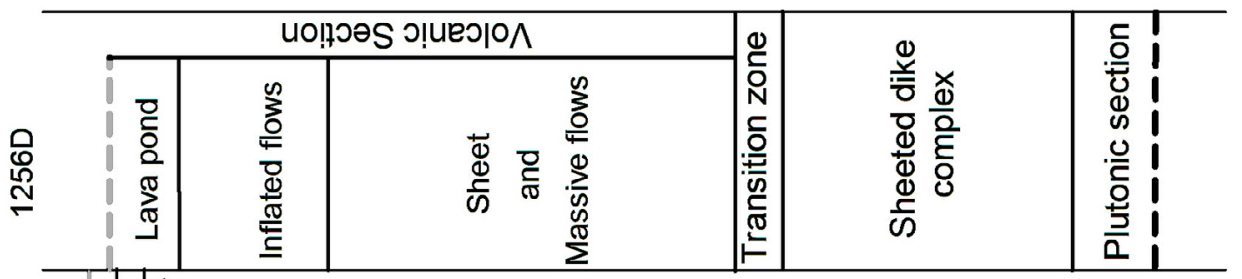

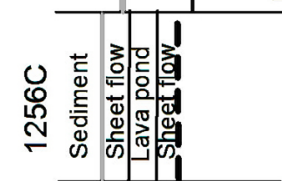

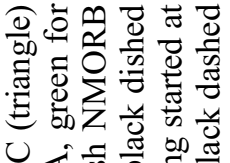

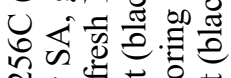

$\therefore$ 它

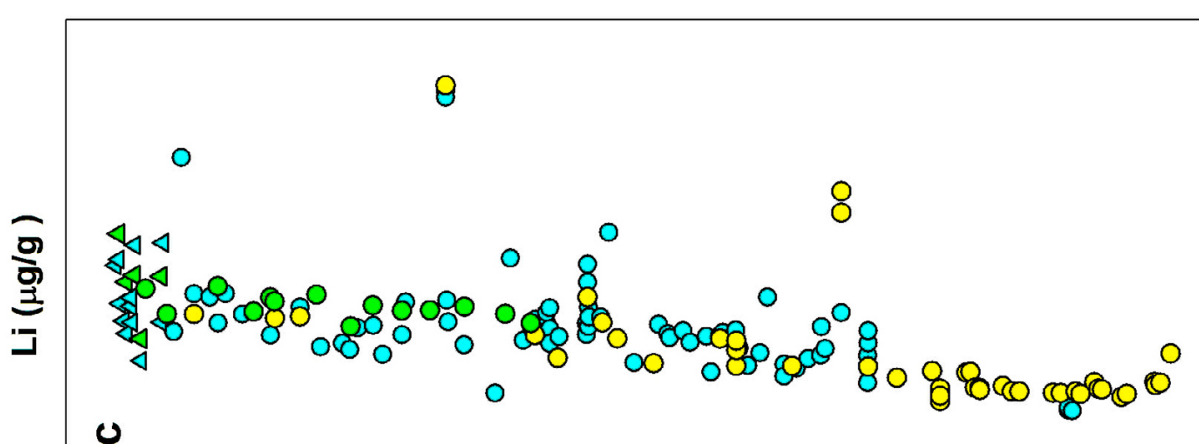

웡

ㄱำ

음

啳

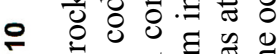

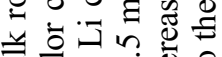

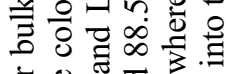

is

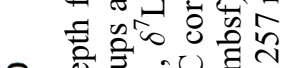

- 융이를

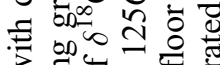

$3 . \Xi 400$

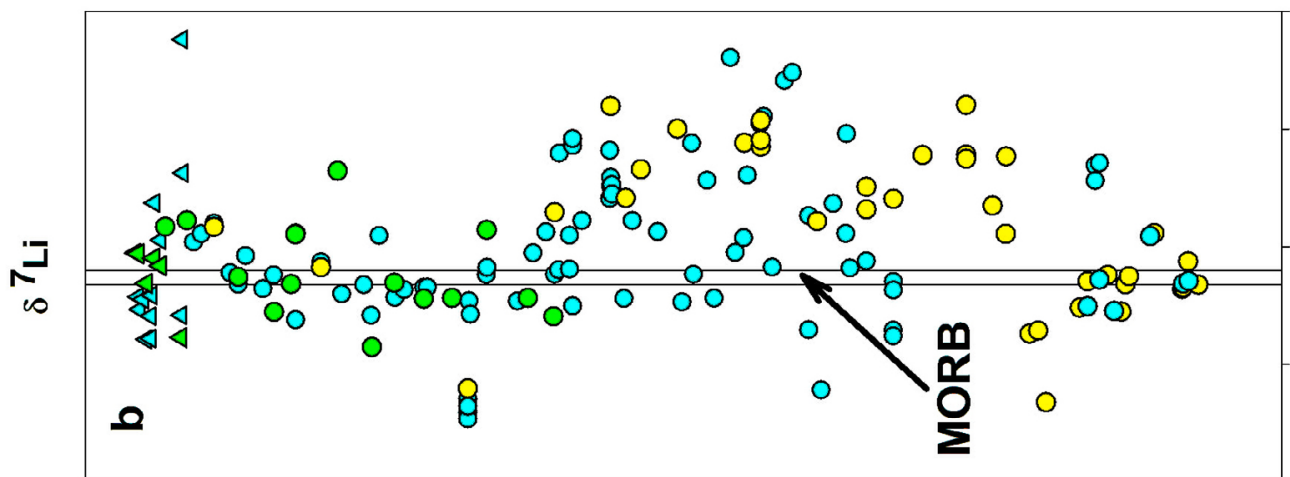

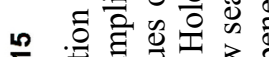

펍

궁

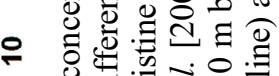

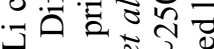

(0)

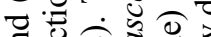

ब

ت.

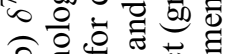

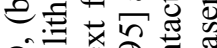

○)

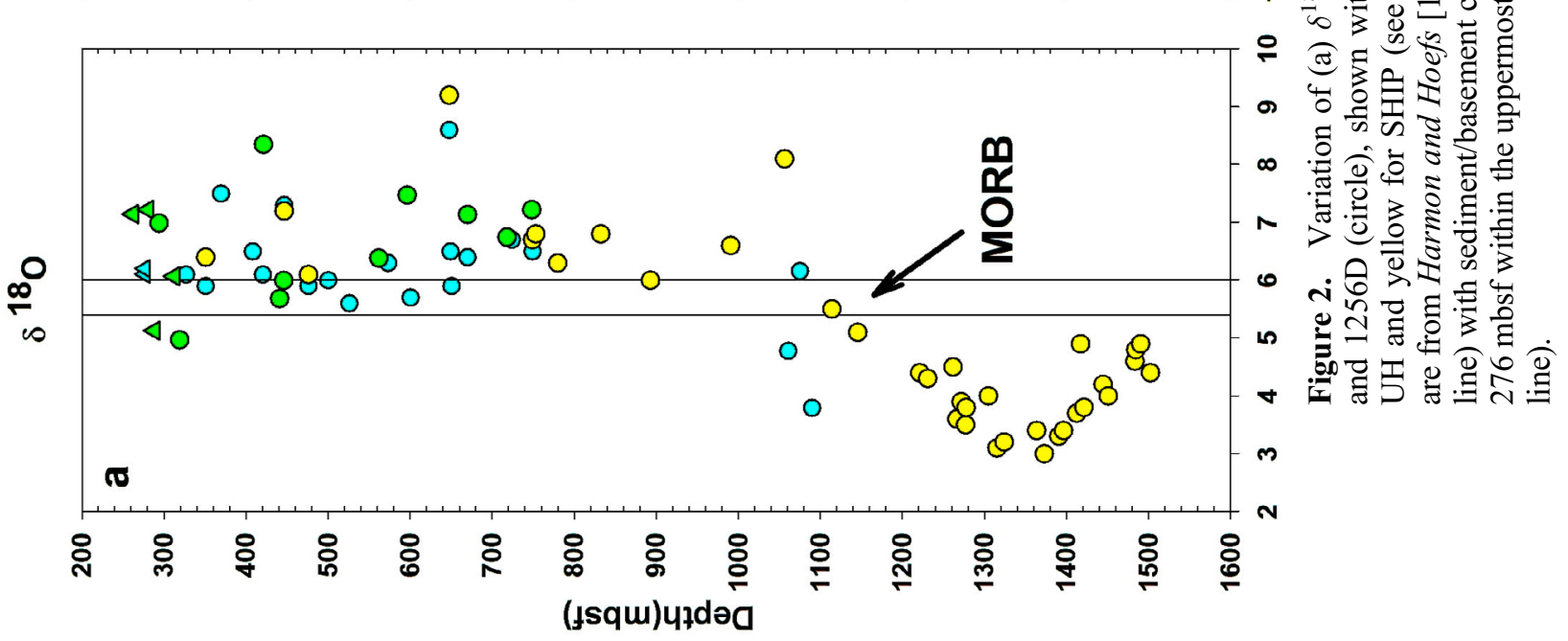




\subsection{Samples and Methods}

[12] The samples studied represent three subsets of materials recovered at Site 1256 during ODP Leg 206 and IODP Expedition 309/312 (Table 1): 1) Shipboard samples that were prepared onboard and analyzed by atomic emission spectroscopy (noted as SHIP); 2) Pool samples, collected and shared by a group of shipboard scientists, were powdered at the National Oceanography Centre Southampton (noted as SA); 3) A set of samples collected from the repository that were powdered at the University of Houston (noted as UH). The SHIP samples were selected to be the freshest observed and to be representative of each igneous unit, although all rocks recovered are partially altered to secondary minerals as a result of fluid-rock interaction [Teagle et al., 2006]. The subset of the Pool samples was selected to be representative of the various types of alteration. The UH samples were selected to mainly cover the upper volcanic sections cored during ODP Leg 206. In order to check the possible sampling bias introduced during sample preparation (i.e., cutting and powdering), the UH sample set includes several samples from the identical, or very close, depth intervals to shipboard AES samples and Pool samples.

[13] For samples prepared at the University of Houston, bulk rock powders were completely digested with mixed acid $\left(\mathrm{HNO}_{3}, \mathrm{HF}\right.$, and $\left.\mathrm{HCl}\right)$ either on hot plate in Savillex ${ }^{\circledR}$ PFA beakers or within an oven in high pressure bombs. The clear solutions obtained after digestion are split into two aliquots for lithium isotope analysis and trace element analysis by ICPMS, respectively [Gao et al., 2009; Gao and Casey, 2011]. The aliquots for lithium isotopic study were first dried down and then re-dissolved in $10 \mathrm{~mL} 0.2 \mathrm{~N} \mathrm{HCl}$ prior to column chemistry. Separation of Li for isotopic composition analysis was achieved by an organic solvent free two-step liquid chromatography procedure in a clean laboratory at the University of Houston following the procedure described by Gao and Casey [2011]. To avoid the problems induced from the usage of organic solvent, such as the degradation of resin, $0.2 \mathrm{~N} \mathrm{HCl}$ was used in both first and second columns to elute $\mathrm{Li}$ [Gao and Casey, 2011]. All separations were monitored by ICP-MS analysis to guarantee both high $\mathrm{Li}$ yield $(>99.8 \%)$ and low $\mathrm{Na} / \mathrm{Li}$ ratio $(<0.5)$. The total chemical procedural blank of $\mathrm{Li}$ was $\sim 0.03 \mathrm{ng}$, which is negligible compared with the samples used in this study with $\geq 100 \mathrm{ng}$ of Li. Lithium isotopic compositions expressed as $\delta^{7} \mathrm{Li}$ relative to $\mathrm{L}-\mathrm{SVEC}$ as $\delta^{7} \mathrm{Li}=$ $\left[\left({ }^{7} \mathrm{Li} /{ }^{6} \mathrm{Li}\right)_{\text {sample }} /\left({ }^{7} \mathrm{Li} /{ }^{6} \mathrm{Li}\right)_{\mathrm{L}-\text { sVEC }}-1\right] \times 1000$ were measured with Nu Plasma MC-ICP-MS at the University of Maryland (UMD) following the procedures described in Rudnick et al. [2004] and Rudnick and Ionov [2007] with a precision of $\leq 1 \%$. The repeated analysis of BHVO-2 (a basalt reference material) during the course of this work yield an average value of $4.3 \% \mathrm{0} \pm 0.2 \%$ [ $\mathrm{Gao}$ and Casey, 2011], which is comparable to the reported value summarized in GeoRem [Jochum et al., 2005].

[14] Samples analyzed at the University of Bristol (UB) had Li separated from matrix using two different protocols. The first data set was acquired by using the methanol- $\mathrm{HNO}_{3}$ method described in Jeffcoate et al. [2004]. After conventional HF-HCl$\mathrm{HNO}_{3}$-digestion, $20 \mathrm{mg}$ aliquots of sample were passed through cation exchange columns using dilute $\mathrm{HNO}_{3}$-methanol/dilute $\mathrm{HCl}$-methanol as an eluent. The second data set used the HCl-cation exchange method after James and Palmer [2000] further discussed in Marschall et al. [2007]. After conventional $\mathrm{HF}-\mathrm{HCl}-\mathrm{HNO}_{3}$-digestion of $100 \mathrm{mg}$ samples including $\mathrm{HClO}_{4}$ for dissolving organic compounds, an up-take of $20 \mathrm{mg}$ in $0.2 \mathrm{~N} \mathrm{HCl}$ were passed through cation exchange columns using $0.2 \mathrm{~N} \mathrm{HCl}$ as an eluent. Samples were then analyzed on a Neptune MC-ICP-MS using a sample-standard bracketing technique relative to the NIST L-SVEC standard [Flesch et al., 1973] as detailed by Jeffcoate et al. [2004] with a $2 \sigma_{\mathrm{SD}}$ external reproducibility of $\pm 0.3 \%$ monitored by multiple analyses of several international rock standards over a period of four years [Pogge von Strandmann et al., 2011]. The sample and standard intensities on the MC-ICPMS were within $10 \%$ of each other.

[15] There is discrepancy between UMD and UB on lithium isotope data for rocks from the same core depth (Table 2). The differences between the two data sets most probably reflect the heterogeneity of lithium isotopes in the studied rocks even at $\mathrm{cm}$ scale. The powders analyzed in the two labs for those "duplicated samples" are not exactly the same powders and were prepared in different laboratories from different pieces of rocks from the same depth (Table 2). There is in general better agreement in the $\mathrm{Li}$ isotope data between the two laboratories for "true duplicated" samples where the same powders were analyzed (Table 2 and Figure 3). For the 5 "true duplicates," the mean differences are $0.75 \%$, and for the pseudo-replicates mean differences are $2.86 \%$ (Table 2).

[16] For most samples oxygen isotopic compositions were analyzed at the University of Goettingen, Germany (UG) and reported as $\delta^{18} \mathrm{O}=$ 


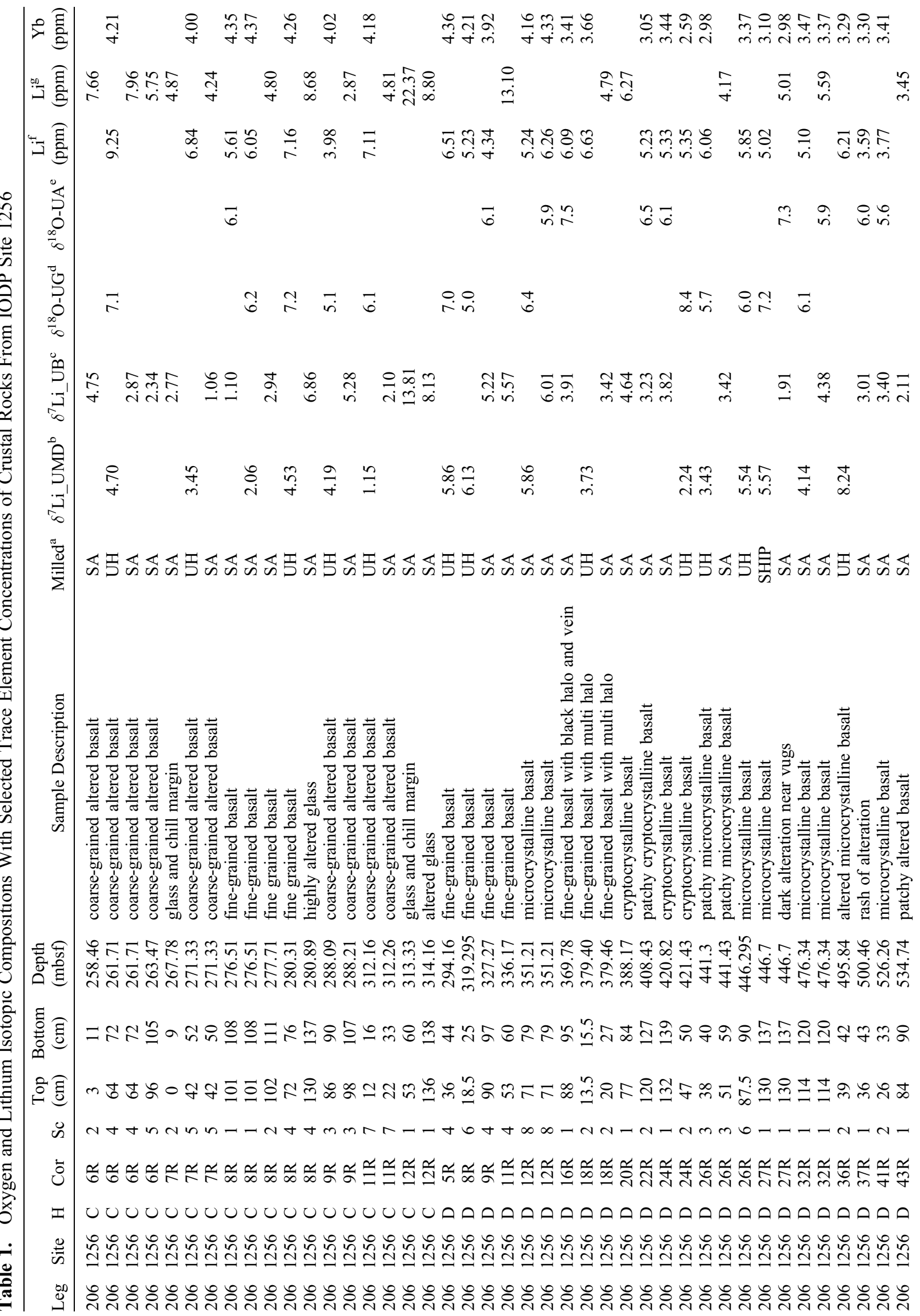




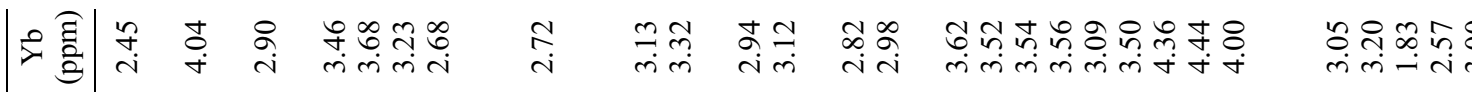

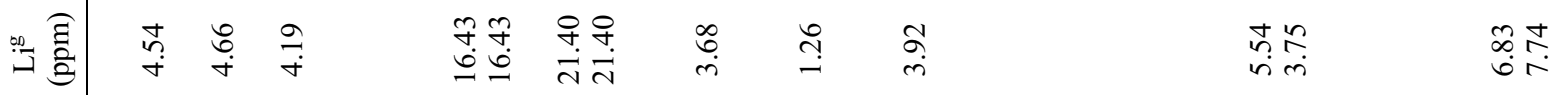

ت

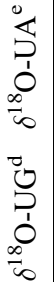

苟

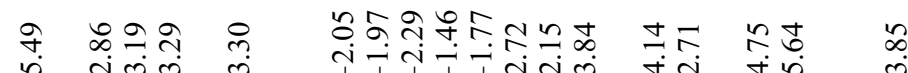

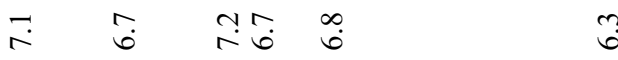

$\stackrel{\circ}{\stackrel{2}{2}}$

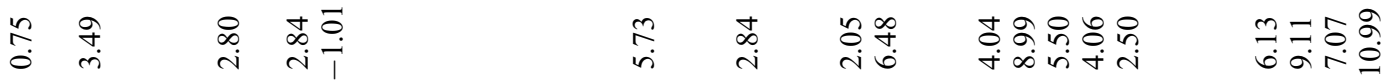

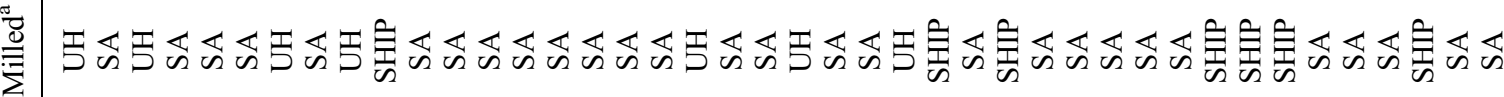

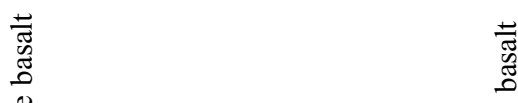

蒠击

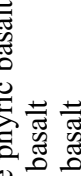

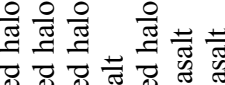

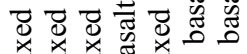

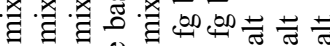

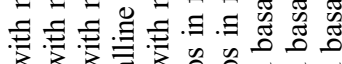

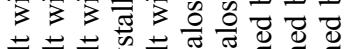

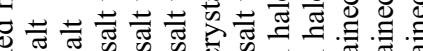

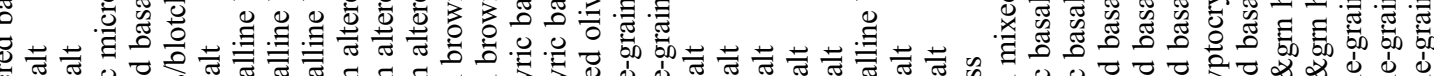

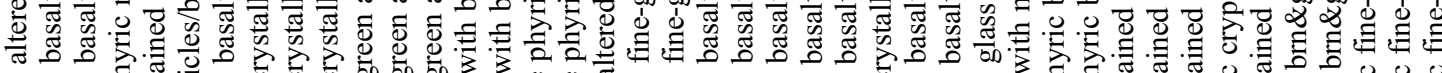

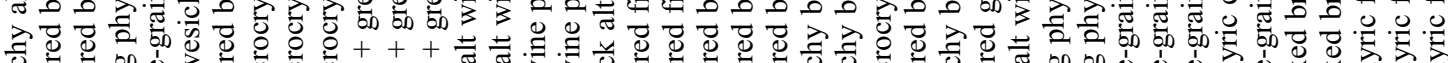

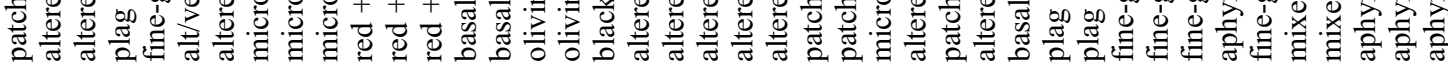

चี

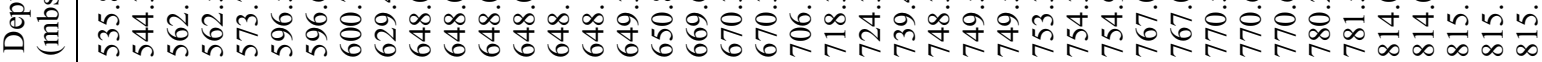

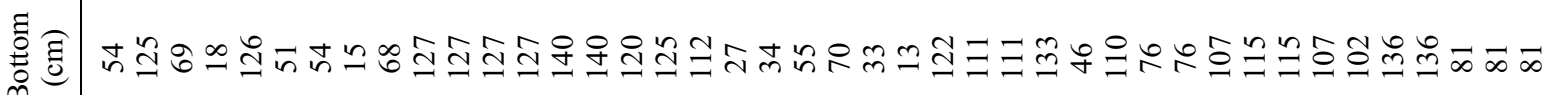

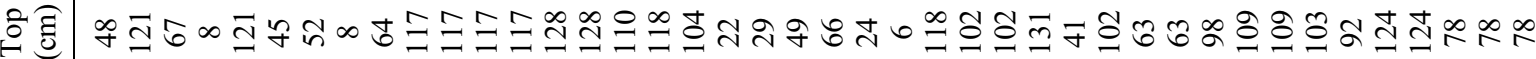

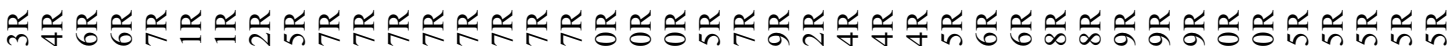

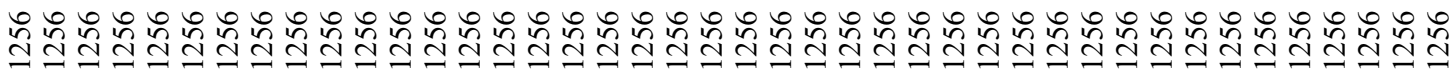




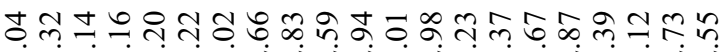

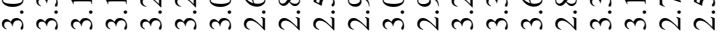
实㐫

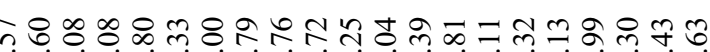

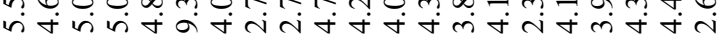

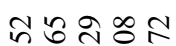

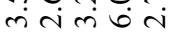

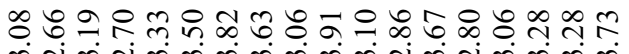

ले

$\quad=$ i

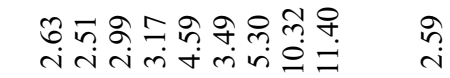
$\stackrel{\infty}{0} \quad \stackrel{0}{0}$
$\stackrel{\circ}{\circ}$
$\vec{\infty} \underset{\infty}{\infty} \underset{+\infty}{\infty}$
$i n$

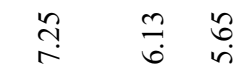

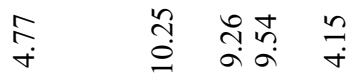

लై

ชี่

尔

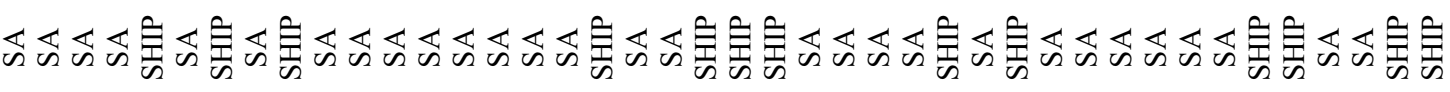

을 을

票票

3

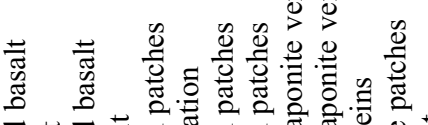

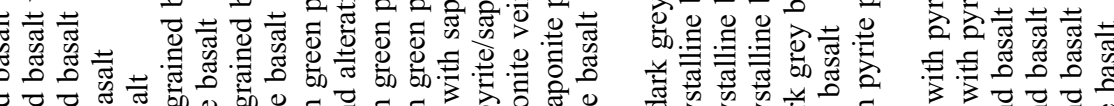

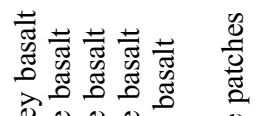

里

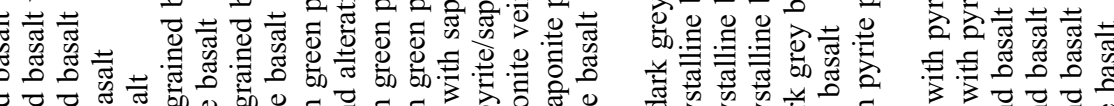

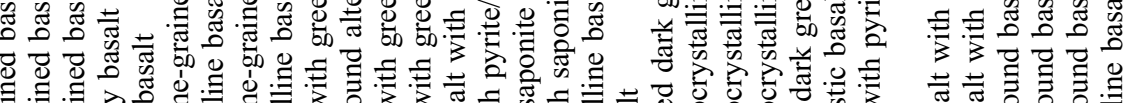

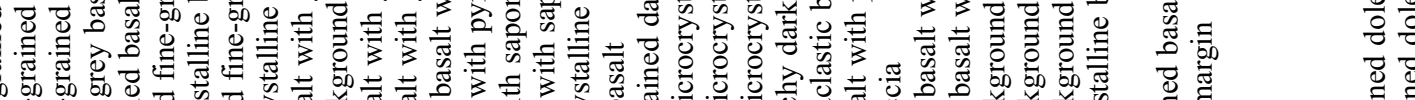

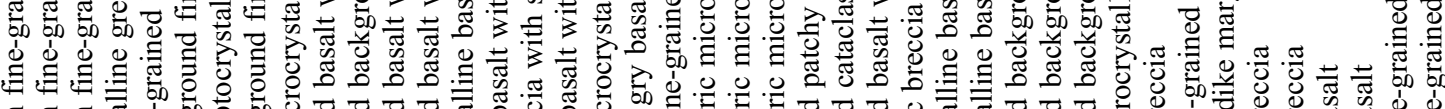

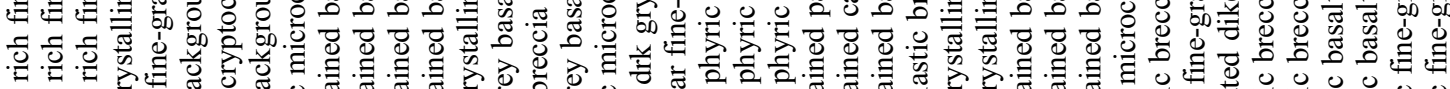
等

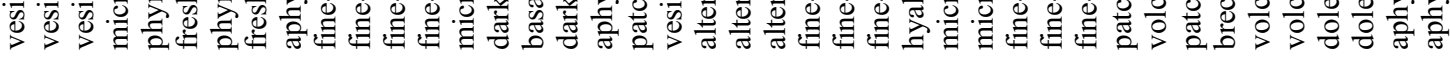

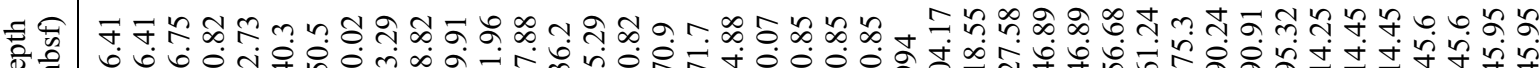
递是

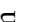

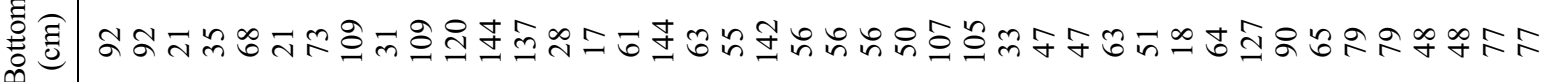

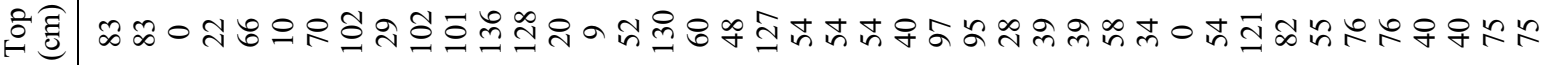

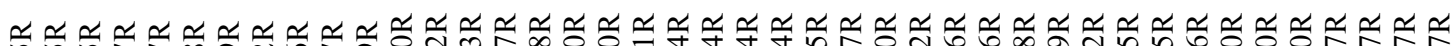

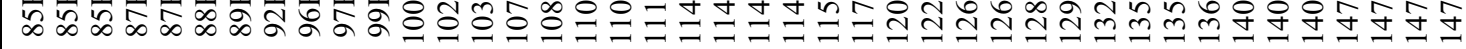

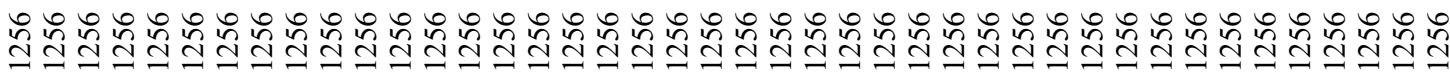




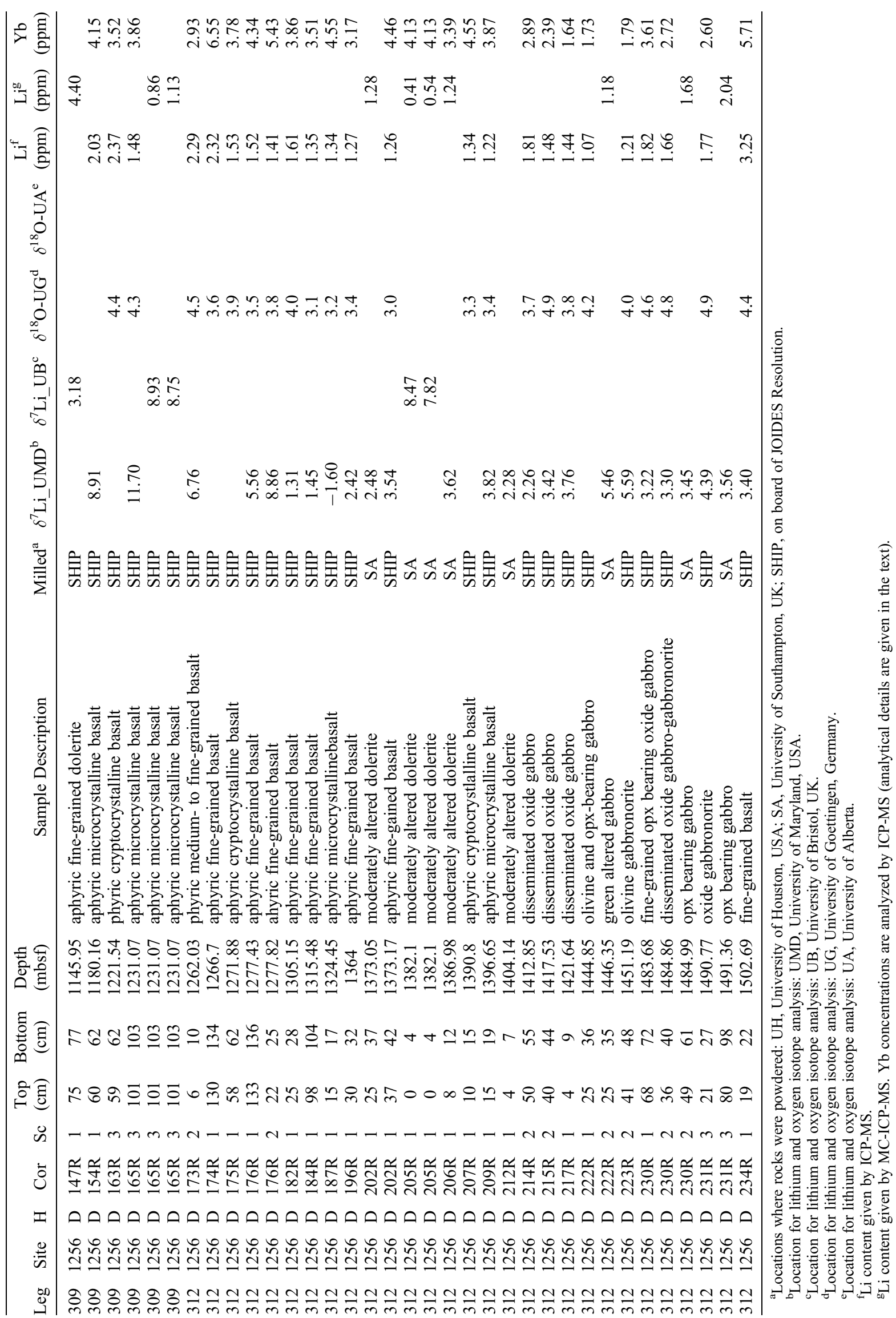


Table 2. Inter-laboratory Comparation for Li Isotope Analysis ${ }^{\mathrm{a}}$

\begin{tabular}{|c|c|c|c|c|c|c|c|c|c|c|c|c|c|}
\hline \multirow[b]{2}{*}{ Leg } & \multirow[b]{2}{*}{ Site } & \multirow[b]{2}{*}{$\mathrm{H}$} & \multirow[b]{2}{*}{ Cor } & \multirow[b]{2}{*}{$\mathrm{Sc}$} & \multirow{2}{*}{$\begin{array}{l}\text { Top } \\
(\mathrm{cm})\end{array}$} & \multirow{2}{*}{$\begin{array}{l}\text { Bottom } \\
(\mathrm{cm})\end{array}$} & \multirow{2}{*}{$\begin{array}{l}\text { Depth } \\
\text { (mbsf) }\end{array}$} & \multicolumn{3}{|c|}{ Analyzed at UMD and UH } & \multicolumn{3}{|c|}{ Analyzed at UB } \\
\hline & & & & & & & & Milled & $\delta^{7} \mathrm{Li} \_\mathrm{UMD}$ & $\mathrm{Li}(\mathrm{ppm})$ & Milled & $\delta^{7} \mathrm{Li} \_\mathrm{UB}$ & $\mathrm{Li}(\mathrm{ppm})$ \\
\hline 206 & 1256 & $\mathrm{C}$ & $6 \mathrm{R}$ & 4 & 64 & 72 & 261.71 & $\mathrm{UH}$ & 4.70 & 9.25 & SA & 2.87 & 7.96 \\
\hline 206 & 1256 & $\mathrm{C}$ & $7 \mathrm{R}$ & 5 & 42 & 52 & 271.33 & $\mathrm{UH}$ & 3.45 & 6.84 & SA & 1.06 & 4.24 \\
\hline 206 & 1256 & $\mathrm{C}$ & $8 \mathrm{R}$ & 1 & 101 & 108 & 276.51 & $S A$ & 2.06 & 6.05 & $\boldsymbol{S A}$ & 1.10 & 5.61 \\
\hline 206 & 1256 & $\mathrm{D}$ & $12 \mathrm{R}$ & 8 & 71 & 79 & 351.21 & $S A$ & 5.86 & 5.24 & $S A$ & 6.01 & 6.26 \\
\hline 206 & 1256 & $\mathrm{D}$ & $27 R$ & 1 & 130 & 137 & 446.7 & SHIP & 5.57 & 5.02 & SA & 1.91 & 5.01 \\
\hline 206 & 1256 & D & $32 \mathrm{R}$ & 1 & 114 & 120 & 476.34 & $S \boldsymbol{A}$ & 4.14 & 5.10 & $S A$ & 4.38 & 5.59 \\
\hline 206 & 1256 & D & $57 \mathrm{R}$ & 2 & 117 & 127 & 648.02 & SHIP & -1.01 & 16.72 & SA & -2.10 & 16.33 \\
\hline 206 & 1256 & $\mathrm{D}$ & $74 \mathrm{R}$ & 2 & 102 & 111 & 749.56 & SHIP & 6.48 & 4.59 & SA & 3.85 & 4.87 \\
\hline 309 & 1256 & D & $85 \mathrm{R}$ & 3 & 78 & 81 & 815.17 & SHIP & 10.99 & 6.09 & SA & 7.78 & 7.29 \\
\hline 309 & 1256 & $\mathrm{D}$ & $114 \mathrm{R}$ & 2 & 54 & 56 & 990.85 & SHIP & 10.37 & 2.63 & SHIP & 9.40 & 3.65 \\
\hline 309 & 1256 & $\mathrm{D}$ & $147 R$ & 1 & 75 & 77 & 1145.95 & SHIP & 7.05 & 2.59 & $\mathrm{SA}$ & 3.35 & 4.09 \\
\hline 309 & 1256 & $\mathrm{D}$ & $165 \mathrm{R}$ & 3 & 101 & 103 & 1231.07 & SHIP & 11.03 & 1.48 & SHIP & 8.84 & 0.99 \\
\hline
\end{tabular}

${ }^{a}$ Table captions are same as Table 1. Duplicated rock powders analyzed in two labs (UMD and UB) could be either the aliqot of the same powders (indicated by bold italic font) or different powders prepared from different pieces of rocks at the same core depths.

$\left[\left({ }^{18} \mathrm{O} /{ }^{16} \mathrm{O}\right)_{\text {sample }} /\left({ }^{18} \mathrm{O} /{ }^{16} \mathrm{O}\right)_{\text {SMow }}-1\right] \times 1000$. Oxygen was extracted from whole rock powders using a laser fluorination technique with a $\mathrm{CO}_{2}$ laser and the produced oxygen was then guided through a purification line to remove the surplus $F_{2}$. The purified oxygen is then transferred into the continuous flow isotope-ratio-monitoring gas chromatography mass spectrometry to analyze the isotope ratios [Gao et al., 2006; Wiechert et al., 2002]. The average analytical precision is generally better than $0.2 \%$ as assessed by duplicate analysis of UWG-2, a garnet reference material [Valley et al., 1995]. A suite of samples from Leg 206 were analyzed at the University of Alberta, Canada (UA) using the conventional BrF5 method of Clayton and Mayeda
[1963] with average reproducibility better than $0.2 \%$.

\section{Results and Discussion}

[17] Lithium and oxygen isotopic compositions along with selected trace element compositions of the rocks from Site 1256 are reported in Table 1 and plotted in Figure 2 (analytical details for trace elements by ICP-MS are given in Gao et al. [2009]).

\subsection{Oxygen Isotopes}

[18] In Holes 1256C and 1256D, the bulk oxygen isotope compositions of igneous rocks range from

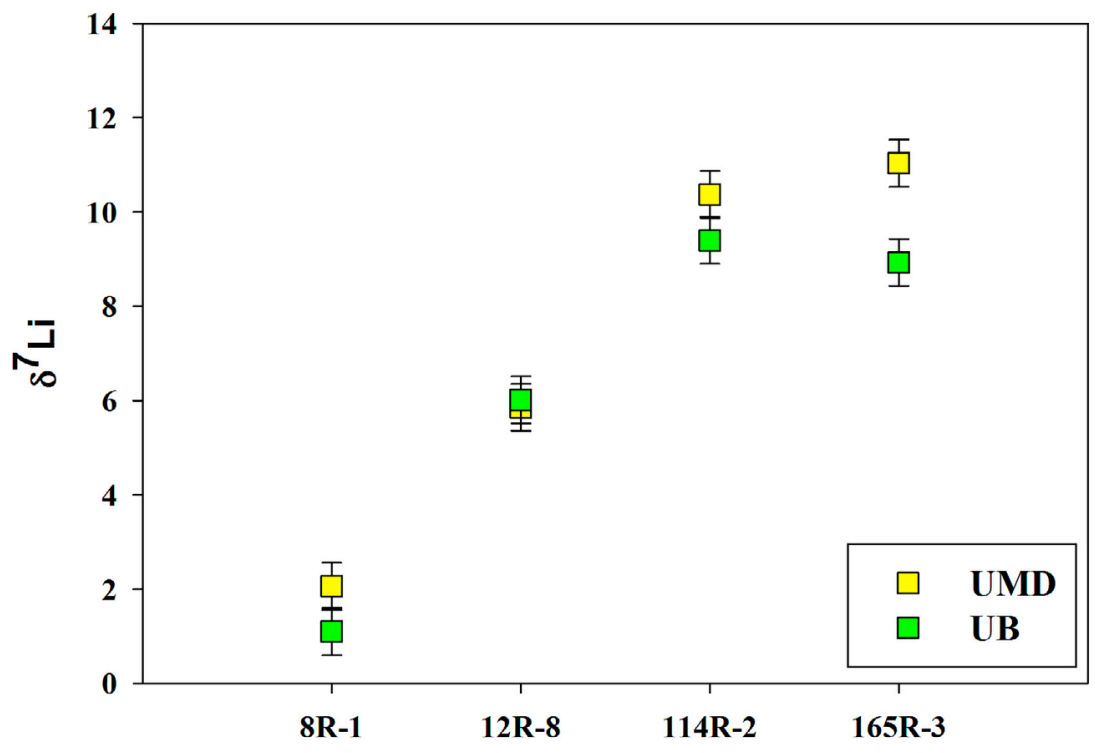

Figure 3. Inter-laboratory comparison of lithium isotope analysis at University of Bristol (UB, filled green square) and University of Maryland (UMD, filled yellow square). The error bar is $1 \%$. 
$\delta^{18} \mathrm{O}=+3.0$ to $+9.2 \%$ (Figure $2 \mathrm{a}$ ). The majority of the extrusive basalts from the upper $1000 \mathrm{~m}$ of Hole $1256 \mathrm{C}$ and $1256 \mathrm{D}$ have heavier oxygen isotope compositions $\left(\delta^{18} \mathrm{O}=+6.1\right.$ to $\left.+9.2 \%\right)$ than fresh MORB (+5.7 $\pm 0.3 \%$ [Harmon and Hoefs, 1995]). Interaction between seawater and oceanic crust at temperatures lower than $250^{\circ} \mathrm{C}$ is known to enrich the volcanic section of the oceanic crust in ${ }^{18} \mathrm{O}[$ Alt and Teagle, 2000; Alt, 2003; Böhlke et al., 1984; Muehlenbachs and Clayton, 1972; Stakes and $\left.O{ }^{\prime} N e i l, 1982\right]$. In Hole 1256D the maximum $\delta^{18} \mathrm{O}$ value occurs at $\sim 650 \mathrm{mbsf}$ within a zone of intensive hydrothermal alteration [Alt et al., 2010]. However, there is no apparent trend for the bulk rock $\delta^{18} \mathrm{O}$ values with depth in the volcanic section (Figure 2a). Similarly, no clear depth trend in the upper volcanic section is reported in Atlantic DSDP holes with ages of 3.2 to $10 \mathrm{Ma}$ (Sites 332, 395 and 396) and $110 \mathrm{Ma}$ (Site 417A [Alt, 2003]). In contrast, in the ODP Holes 504B and 896A (6.9 Ma) in the Eastern Pacific a general downward decrease in the bulk rock $\delta^{18} \mathrm{O}$ values is observed [Alt et al., 1996, 1986; Teagle et al., 1996].

[19] A change from enriched to depleted $\delta^{18} \mathrm{O}$ values compared to fresh MORB occurs at the depth of $\sim 1100$ mbsf near the top of the sheeted dike complex. This ${ }^{18} \mathrm{O}$ depletion is accompanied by the occurrence of chlorite, actinolite, epidote, and albite, typical for greenschist alteration [Teagle et al., 2006]. This transition in $\delta^{18} \mathrm{O}$ values indicates the change of alteration conditions from lower to higher temperatures $\left(>250^{\circ} \mathrm{C}\right)$ within the sheeted dike complex.

[20] In the sheeted dike complex there is a clear trend of decreasing whole rock $\delta^{18} \mathrm{O}$ values to a minimum $\delta^{18} \mathrm{O} \sim 3 \%$ at $\sim 1373$ mbsf. Below this depth, the $\delta^{18} \mathrm{O}$ values increase toward the fresh MORB $\delta^{18} \mathrm{O}$ value within the plutonic section. The $\delta^{18} \mathrm{O}$ minimum in the lower sheeted dikes approximately coincides with the minimum value of $\delta^{7} \mathrm{Li}$ (Figure 2) and the maximum depletion of $\mathrm{Li}$ indicated by the low Li/ $/ \mathrm{Yb}$ ratio (Figure 4).

\subsection{Lithium Contents and Isotopic Composition}

[21] Reported $\delta^{7} \mathrm{Li}$ values of MORB are highly variable ranging between +1.5 and $+6.5 \%$ [ [Chan et al., 1992; Moriguti and Nakamura, 1998; Tomascak and Langmuir, 1999; Tomascak et al., 2008]. The heterogeneity of $\mathrm{Li}$ isotopes in the upper mantle has been largely attributed to recycling of subducted material [Elliott et al., 2004, 2006;
Nishio et al., 2004]. Evidence from isotopic signatures of OIB and MORB led to the proposition of a large and homogeneous reservoir in the upper mantle with a $\delta^{7} \mathrm{Li}$ value of $+4 \%$ [ Ryan and Kyle, 2004; Tomascak et al., 2002]. A newer study estimated the N-MORB $\delta^{7} \mathrm{Li}$ value to be $+3.4 \%$ [Tomascak et al., 2008], similar to the reported $\delta^{7} \mathrm{Li}$ value of the pristine upper mantle (about $+3.5 \%$ [Jeffcoate et al., 2007; Magna et al., 2006]).

\subsubsection{Lithium Contents}

[22] The bulk rocks show a general trend of decreasing lithium concentrations with depth, except for few local zones of strongly elevated or depleted Li contents (Figure 2c). The average Li concentration in fresh EPR MORBs has been reported to be $7.2 \mu \mathrm{g} / \mathrm{g}$ [Tomascak et al., 2008]. Li concentration of $\sim 3 \mu \mathrm{g} / \mathrm{g}$ was used by Chan et al. [2002] as pristine value to investigate the $\mathrm{Li}$ exchange due to alteration in the rocks from Holes 504B and 896A. As an incompatible element Li contents are expected to vary during crystal fractionation [Ryan and Langmuir, 1987; Brenan et al., 1998a]. In Hole $1256 \mathrm{D}$, basaltic rocks have $\mathrm{MgO}$ content ranging from 3.5 to $11 \mathrm{wt} \%$ (Figure $4 \mathrm{a}$ ), indicating a significant range of fractionation [Wilson et al., 2003, 2006; Teagle et al. 2006; Neo et al., 2009]. Thus, it is unlikely that a single uniform Li concentration can be used as a baseline to justify the changes in Li contents induced by alteration.

[23] $\mathrm{Li}$ and $\mathrm{Yb}$ exhibit similar magmatic incompatibility and are essentially unfractionated from each other during crustal low-pressure crystallization processes [Brenan et al., 1998a, 1998b; Ryan and Langmuir, 1987]. However, due to the fluid mobility of $\mathrm{Li}$, these two elements will be strongly fractionated by water-rock interactions [Brenan et al., 1998b]. Based on the available data given in petDB (http://www.petdb.org [Lehnert et al., 2000]), fresh MORB glasses from EPR have an average $\mathrm{Li} / \mathrm{Yb}$ ratio of 1.75, which is similar to the global mean of 1.7 [Ryan and Langmuir, 1987]. Thus the measured $\mathrm{Li} / \mathrm{Yb}$ ratio can serve as a good indicator of the $\mathrm{Li}$ variation due to alteration. The $\mathrm{Li} / \mathrm{Yb}$ ratios in the rocks from Site 1256 are generally less than 1.75 (Figure $4 \mathrm{~b}$ ), indicating the loss of $\mathrm{Li}$ from the rocks. Above $\sim 900$ mbsf, lithium contents show variation with both high and low $\mathrm{Li} / \mathrm{Yb}$ ratios, though low $\mathrm{Li} / \mathrm{Yb}$ ratios are most common in this upper section. Local zones with significant change in Li content occur near the base of the lava pond ( $\sim 350 \mathrm{mbsf})$, and at $\sim 650 \mathrm{mbsf}$ and $\sim 850 \mathrm{mbsf}$, where there is anomalously strong hydrothermal alteration and the occurrence of smectite-chlorite mixtures [see Alt 

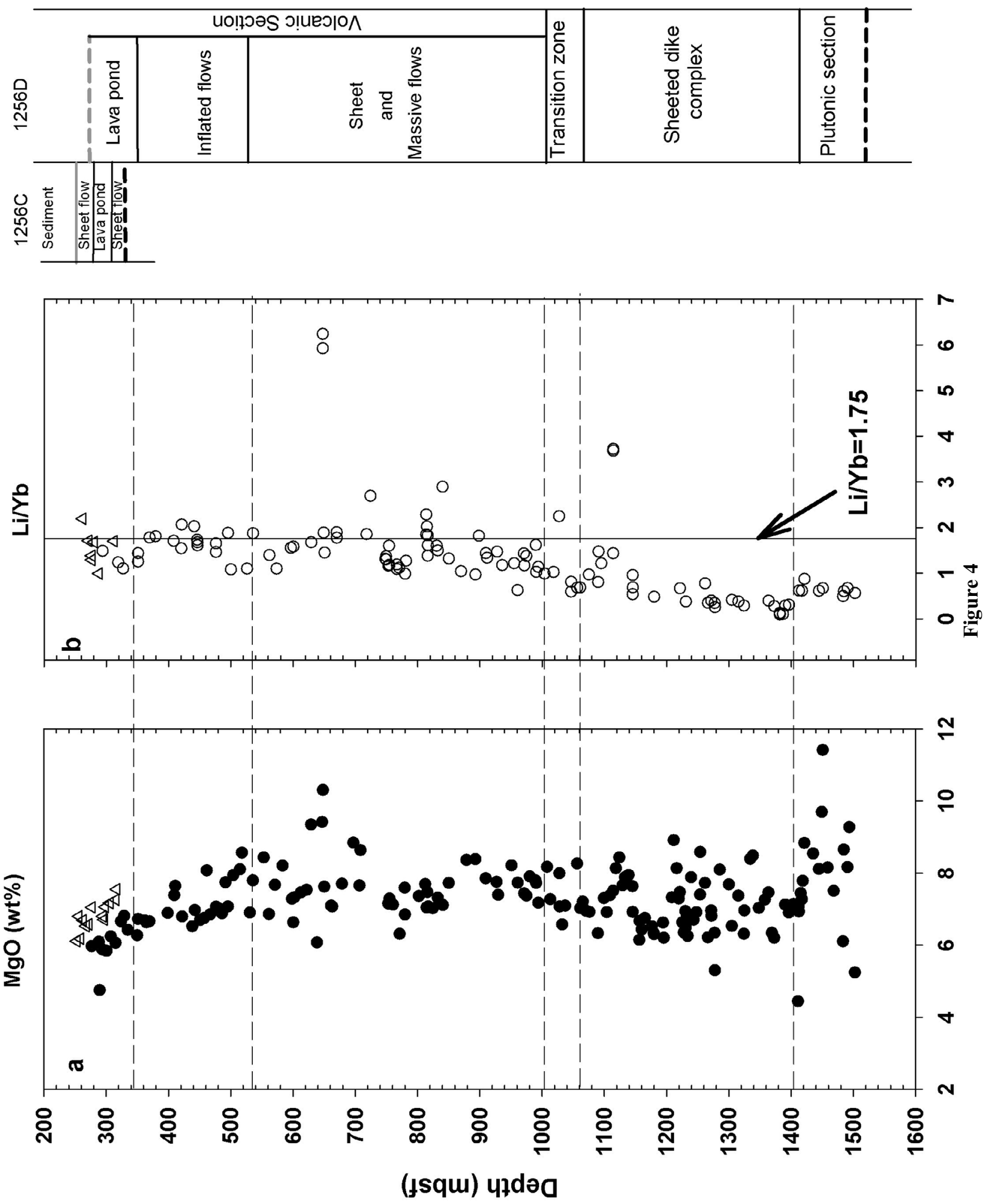
et al., 2010]. Below 900 mbsf, the Site 1256 crust is dominated by rocks with depleted lithium contents relative to fresh MORB, except for a few localized enrichments within or close to the transition zone. In the sheeted dike complex the $\mathrm{Li} / \mathrm{Yb}$ ratio decreases gradually with depth and reaches a minimum value at $\sim 1350$ mbsf (Figure $4 b$ ), which indicates the gradual loss of lithium. Rocks in the plutonic section have slightly higher Li contents than in the overlying granoblastic dikes.

[24] During hydrothermal alteration, Li is mobilized during the destruction and recrystallization of silicate minerals. Depending on the reaction temperature, secondary minerals such as chlorites, smectite, zeolite, and epidote may incorporate some or none of the Li released from the primary phases [Berger et al., 1987, 1988; James et al., 2003, Pabst et al., 2011]. The uptake of Li into secondary minerals can occur by both surface adsorption and mineral structural incorporation via lattice substitution [Berger et al., 1988; Vigier et al., 2008]. Experiments show that the Li partition coefficients in clay minerals decrease with increasing temperature and such phases can be sources of $\mathrm{Li}$ in fluids at higher temperatures [Berger et al., 1988; James et al., 2003; Magenheim et al., 1995; Seyfried et al., 1984; Von Damm et al., 1985]. At low temperatures $\left(<150^{\circ} \mathrm{C}\right)$, basalts take up seawater Li through formation of alteration phases such as clay minerals [e.g., Chan et al., 1992; James et al., 2003; Seyfried et al., 1984]. The uptake of Li into secondary minerals can occur by both structural incorporation and surface adsorption which is enhanced at low temperature [Berger et al., 1988; Vigier et al., 2008]. In contrast, at temperatures above the upper stability of clay minerals $\left(\sim 200^{\circ} \mathrm{C}\right)$, $\mathrm{Li}$ is leached from basalts [e.g., Chan et al., 1993, 2002; Seyfried et al., 1984, 1998; Von Damm et al., 1985].

[25] Collectively, the overall low Li contents of rocks from the sheeted dikes and plutonic section (Figure 4c) most likely reflects fluids-rock interactions at elevated temperatures $\left(>200^{\circ} \mathrm{C}\right)$. Despite the lower alteration temperatures suggested by the generally elevated oxygen isotope compositions (Figure 2a), the upper volcanic section also shows a global depletion of Li contents, albeit with significant variation (Figure 4c). This is in contrast to Hole
504B, where the volcanic section was dominated by $\mathrm{Li}$ enrichment owing to the alteration by large volumes of seawater, freely circulating through the uppermost volcanic pile [Alt et al., 1996; Chan et al., 2002]. The observed overall Li depletion in Site 1256 volcanic section may indicate variable but generally low $\mathrm{w} / \mathrm{r}$ ratios in this part. Due to the large difference of Li concentration between seawater and fresh basaltic rocks, the bulk rock $\mathrm{Li}$ composition of altered oceanic crust is highly sensitive to the water/rock (w/r) ratio, especially under rock-dominated conditions. The quantitative modeling given in the following section shows that the enrichment of $\mathrm{Li}$ in altered oceanic crust at low temperature requires a very high $\mathrm{w} / \mathrm{r}$ ratio. In contrast, low $\mathrm{w} / \mathrm{r}$ ratios could lead to Li depletion in bulk rocks even at low temperature.

[26] In general, the observed downhole Li variation trend is consistent with the abundance of secondary minerals and the oxygen isotope values of alteration veins at Hole 1256D. These show downward increasing temperatures from 50 to $110^{\circ} \mathrm{C}$ in the volcanic section to $250-350^{\circ} \mathrm{C}$ across the transition zone [Alt et al., 2010].

\subsubsection{Lithium Isotopic Compositions}

[27] From the upper volcanic section down to $\sim 750$ mbsf the profile at Site 1256 is characterized by a wide spread of $\delta^{7} \mathrm{Li}$ values $(-2.29 \%$ o to $+13.81 \%$ ) both lower and higher than fresh MORB (Figure 2). This trend is in contrast to observations from Hole 504B, where the upper volcanic section is dominated by enriched $\delta^{7} \mathrm{Li}$ values that generally decrease with depth [Chan et al., 2002]. A wide spread of $\mathrm{Sr}$ isotope ratios $\left({ }^{87} \mathrm{Sr} /{ }^{86} \mathrm{Sr}\right)$ has been reported in the upper volcanic zone of Troodos ophiolite as a result of non-pervasive fluid-rock alteration and kinetically limited process [Bickle and Teagle, 1992]. At Site 1256, the variable $\delta^{7} \mathrm{Li}$ values and the overall depleted Li concentrations of the altered basalts may suggest that in this volcanic zone the fluid circulation was also highly localized. The fluids that circulated within the Site 1256 crust appear to have evolved and variable $\delta^{7} \mathrm{Li}$ and $\mathrm{Li}$ contents resulted from mixing of downwelling seawater and upwelling hydrothermal fluids. The minimum $\delta^{7} \mathrm{Li}$ value observed at $650 \mathrm{mbsf}$ is associated with the highest $\delta^{18} \mathrm{O}$ and maximum

Figure 4. Variation of (a) $\mathrm{MgO}$ and (b) $\mathrm{Li} / \mathrm{Yb}$ with depth for bulk rocks from Hole 1256C and 1256D, shown with lithologic sections. The data sources for $\mathrm{MgO}$ content in wt $\%$ are: Wilson et al. [2003], Wilson et al. [2006], Teagle et al. [2006], and Neo et al. [2009]. The igneous value of Li/Yb is given as 1.75 based on the compiled fresh basalts from the east pacific rise (EPR, see text for details). Symbols are same as Figure 2. 

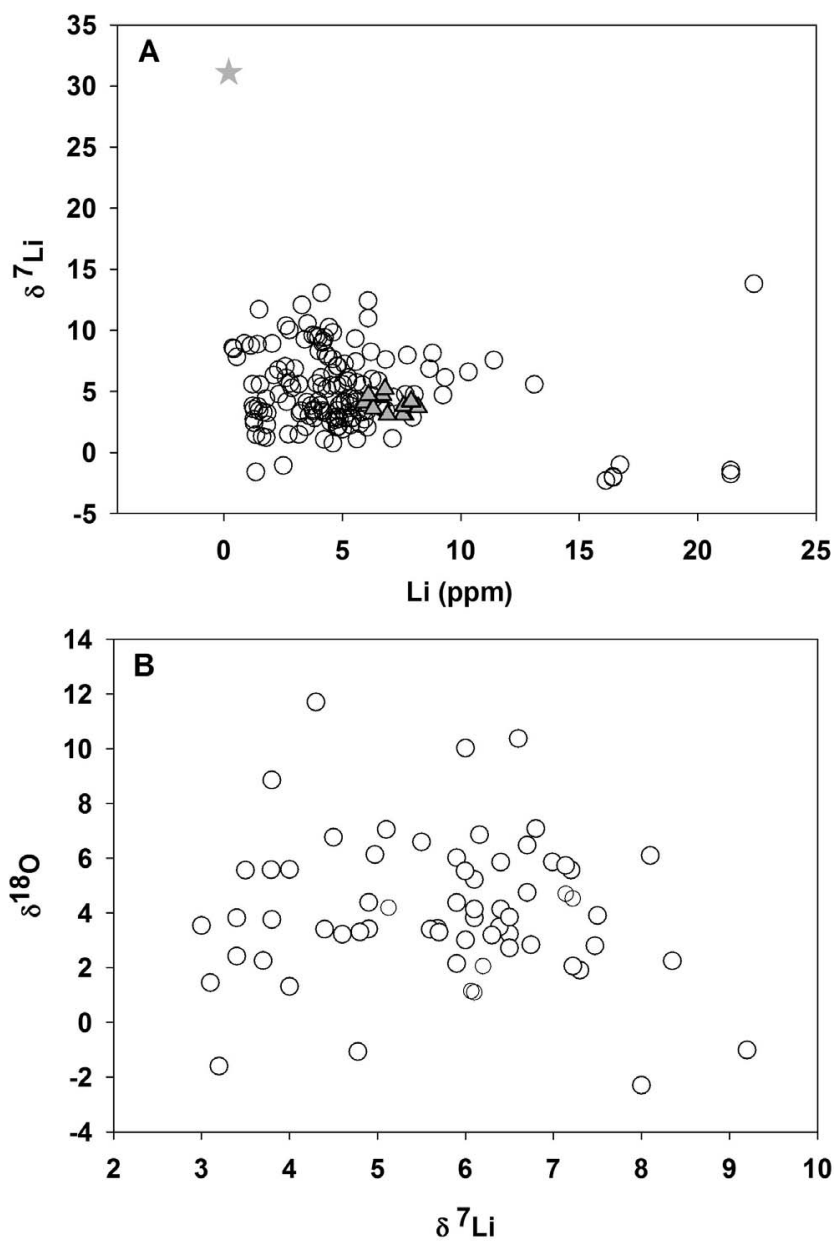

Figure 5. Relationships of (a) $\delta^{7} \mathrm{Li}$ with $\mathrm{Li}$ content and (b) $\delta^{18} \mathrm{O}$ in whole rocks from IODP site 1256 (open circle). The values of $\mathrm{Li}$ and $\delta^{7} \mathrm{Li}$ for fresh MORB glass from east pacific rise (gray filled triangle [Chan et al., 1992; Elliott et al., 2006; Tomascak et al., 2008]) and seawater (gray filled star [Chan et al., 1992]) are also shown.

Li concentration. This may be a localized zone in the upper volcanic section where upwelling hydrothermal fluids are being discharged at low temperature. Compared to unmodified seawater $(0.2 \mu \mathrm{g} / \mathrm{g} \mathrm{Li}$, $+31 \% \delta^{7} \mathrm{Li}$, and $0 \% \delta^{18} \mathrm{O}$ [Chan et al., 1992]), hydrothermal fluids have been reported to have an average content of about $10 \mu \mathrm{g} / \mathrm{g} \mathrm{Li}, \delta^{7} \mathrm{Li}$ of $+7.5 \%$, and $\delta^{18} \mathrm{O}$ of up to $+8 \%$ [Chan et al., 1993; Bray, 2001; Chan et al., 2002, Gregory and Taylor, 1981]. The $\delta^{7} \mathrm{Li}$ maximum together with the elevated $\mathrm{Li}$ concentrations near the base of the lava pond at $\sim 310 \mathrm{mbsf}$ in Hole $1256 \mathrm{C}$ and $\sim 350$ mbsf in Hole 1256D (Figure 2) may result from enhanced lateral seawater circulation at this location or alternately could represent a former paleo-ocean floor, prior to being sealed by the overlying lava pond [Alt et al., 2010].

[28] Sheet and massive flows and sheeted dikes below $\sim 750 \mathrm{mbsf}$ are dominated by high $\delta^{7} \mathrm{Li}$ values compared to fresh MORB which continue across the transition zone to the lower sheeted dike complex (Figure 2b). From $\sim 1280 \mathrm{mbsf}$ in the lower sheeted dike complex, $\delta^{7} \mathrm{Li}$ values show a steep gradient from high to low values. A minimum value of $\delta^{7} \mathrm{Li} \sim-1.6 \%$ occurs at $\sim 1350 \mathrm{mbsf}$ approximately coincident with the minimum value of $\delta^{18} \mathrm{O}$. Below this level, the bulk $\delta^{7} \mathrm{Li}$ values start to generally increase toward the fresh MORB composition $(+3.4 \%)$.

[29] The Li isotopic composition correlates with neither Li concentration nor oxygen isotopic composition for whole rock samples from Site 1256 (Figure 5). This is in contrast to the observation at Hole 504B, where good positive correlations among $\mathrm{Li}, \delta^{7} \mathrm{Li}$, and $\delta^{18} \mathrm{O}$ have been reported [Chan et al., 2002]. As shown in the following discussions, this may reflect the difference in fluid-rock reaction passes related to the different seawater/hydrothermal circulation patterns between these two sites. 


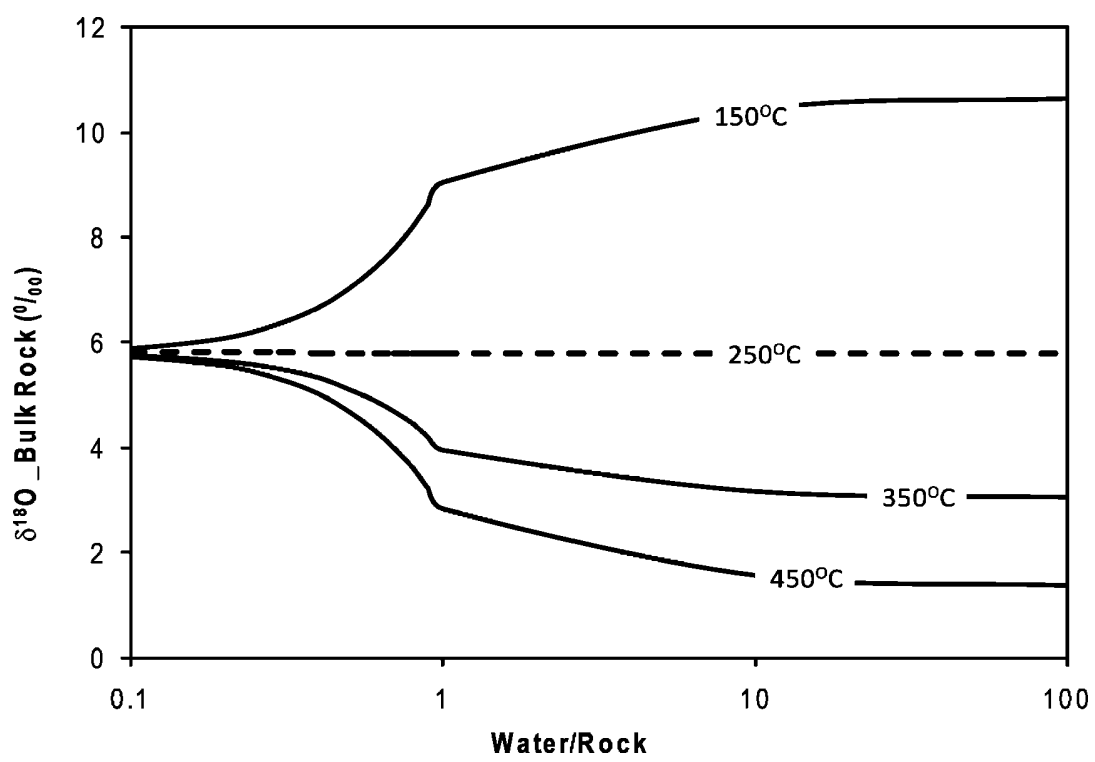

Figure 6. Modeling calculations illustrate the variation of oxygen isotope compositions of bulk rocks and fluids with water/rock ratios and temperatures during interaction of basalt with seawater (see text for details of the modeling).

\subsubsection{Sampling Bias}

[30] To check the potential effect of sampling strategies, analytical results were plotted by colorcoded symbols to denote the different sample set (i.e., SHIP, SA, and UH). Generally, the UH and SA data set show a broader variation for lithium isotopes at given depth compared to the SHIP data set. This reflects the fact that the SHIP samples were selected to be the freshest and the most representative rock in each igneous unit, whereas SA and UH samples were selected to be representative of the various types of alteration. However, the discrepancies among the three sample set does not mute the overall depth variation trend. For example, as shown in Figure 2, the SHIP data defined a trend that the upper volcanic section has a wide spread of $\delta^{7} \mathrm{Li}$ values though it was dominated by fresh MORB like values, while the rocks below $\sim 750$ mbsf down to $\sim 1300 \mathrm{mbsf}$ are dominated by high $\delta^{7} \mathrm{Li}$ values compared to fresh MORB. This observed overall trend doesn't change when SA and UH data set are added to the plot, though it shows a much more scattered patterns at given depth. Most probably, this reflects the fact that all rocks recovered have been pervasively but variably altered to secondary minerals as a result of fluid-rock interaction which might be more intense at locations with concentrated alteration halos and/ or veins [Teagle et al., 2006].

[31] Thus, we believe that the obtained depth profile is representative and not greatly affected by the multiple sampling strategies and/or by the multiple techniques and locations used for separating and measuring $\mathrm{Li}$ isotopes.

\subsection{Hydrothermal Circulation at a Superfast Spreading Ridge}

[32] The distribution, characteristics and intensity of seawater circulation within the oceanic crust are controlled by the thermal regime and permeability structure and these are strongly influenced by magmatic and tectonic processes. Elemental and isotopic exchanges during water-rock interaction leave fingerprints the evolving conditions of hydrothermal circulation.

\subsubsection{Quantitative Modeling}

[33] The relationship between $\delta^{18} \mathrm{O}$ values of the altered igneous rock $\left(\delta_{\mathrm{r}}^{\mathrm{f}}\right)$ and the water/rock ratios based on atom percent oxygen $(\mathrm{W} / \mathrm{R})_{\mathrm{A}}$ in closed systems, was defined by Taylor [1977] to be $(\mathrm{W} / \mathrm{R})_{\mathrm{A}}$, closed system $=\left(\delta_{\mathrm{r}}^{\mathrm{f}}-\delta_{\mathrm{r}}^{\mathrm{i}}\right) /\left(\Delta-\delta_{\mathrm{r}}^{\mathrm{f}}\right)$. In this formula, $\Delta$ is the temperature dependent equilibrium fractionation constant between rock and water assumed to be equal to that of $\mathrm{H}_{2} \mathrm{O}$-plagioclase $\left(\mathrm{An}_{50}\right)$ to mimic the basaltic bulk rock, $\delta_{\mathrm{r}}^{1}$ is the initial $\delta^{18} \mathrm{O}$ value of unaltered igneous rock.

[34] Figure 6 illustrates how water/rock ratio and alteration temperature can affect the oxygen isotope composition of bulk rocks. Our model assumes that the amount of rock exchanging oxygen with the fluid is determined by the relative mass of fluid and rock (the water/rock ratio). In such a case, at $(\mathrm{W} / \mathrm{R})_{\mathrm{A}} \geq 1$ 
the entire rock is equilibrated with the fluid uniformly, at $(\mathrm{W} / \mathrm{R})_{\mathrm{A}}<1$ only a portion of the rock can exchange oxygen isotope with fluid and the remaining part retains its igneous composition. Hence the $\delta^{18} \mathrm{O}$ value of bulk rock given in Figure 6 reflects a mass balance of alteration and primary phases at various water/rock ratios. As shown in Figure 6, where basaltic rock $\left(\delta^{18} \mathrm{O}=+5.7 \%\right)$ reacts with seawater $\left(\delta^{18} \mathrm{O}=0 \%\right)$ at different temperatures, the oxygen isotope composition of bulk rock is dominantly determined by the alteration temperature, especially at greater water/rock ratios. In these examples, the bulk rocks are depleted in ${ }^{18} \mathrm{O}$ at elevated temperatures $\left(\geq 250^{\circ} \mathrm{C}\right)$, whereas at lower temperatures rocks become enriched in ${ }^{18} \mathrm{O}$. Thus, the obtained bulk rock $\delta^{18} \mathrm{O}$ values are most useful to constrain alteration temperatures.

[35] The behavior of lithium isotopes during rockwater interaction under equilibration is described in the following two equations given by Magenheim et al. [1995], where Li is partitioned into the fluid and alteration phases assuming the rock is incrementally destroyed.

$$
\begin{gathered}
R / W=-K^{-1} \times \ln \left(\frac{X_{R}-K X}{X_{R}-K X_{o}}\right) \\
R / W=-(\alpha K)^{-1} \times \ln \left(\frac{Y_{R}-\alpha K Y}{Y_{R}-\alpha K Y_{o}}\right)
\end{gathered}
$$

$\mathrm{R} / \mathrm{W}$ is rock/water ratio in weight units, $\mathrm{K}$ is distribution coefficient of Li between rock and fluid at given temperature, $\alpha$ is equilibrium fractionation factor between rock and water, $\mathrm{X}, \mathrm{X}_{\mathrm{R}}$ and $\mathrm{Y}, \mathrm{Y}_{\mathrm{R}}$ are the concentrations of ${ }^{6} \mathrm{Li}$ and ${ }^{7} \mathrm{Li}$ in alteration products and final fluids respectively, $X_{o}$ and $Y_{o}$ are the initial concentrations of ${ }^{6} \mathrm{Li}$ and ${ }^{7} \mathrm{Li}$ in the starting fluid.

[36] The distribution coefficient $\mathrm{K}$ varies with temperature, with a tendency of becoming more incompatible to basaltic rock with increasing temperature [Berger et al., 1988; Seyfried and Bischoff, 1981; Seyfried et al., 1998]. In this model, $\mathrm{K}=0.15-0.35$ are used for the temperature range of $250^{\circ} \mathrm{C}-500^{\circ} \mathrm{C}$ based on the proposed values by Chan et al. [2002] and adjusted based on the existing experimental results [Berger et al., 1988; Seyfried et al., 1998; Vigier et al., 2008]. For low temperature range of $2^{\circ} \mathrm{C}-200^{\circ} \mathrm{C}, \mathrm{K}$ of $2-200$ are proposed based on the experimental results between a fresh natural basaltic glass and seawater at $150^{\circ} \mathrm{C}$ with $\mathrm{w} / \mathrm{r}$ mass ratio of 10 [Seyfried et al., 1984]. It is worth noting that the obtained bulk partition coefficient of $\sim 120$ at $150^{\circ} \mathrm{C}$ by Seyfried et al. [1984] is much higher than the experimentally determined partition coefficients for any clay minerals which are the main hosts for $\mathrm{Li}$ in the altered basalt. For example, $\mathrm{K}=2.3$ and $\mathrm{K}=8.5$ at $150^{\circ} \mathrm{C}$ for zeolite and smectite were derived from an experimental study on the hydrothermal reaction with a synthetic basaltic glass [Berger et al., 1988]. Thus the adopted partition coefficients of $\mathrm{Li}$ at low temperatures in our model represent an upper limit.

[37] The isotopic fractionation factors of $\mathrm{Li}$ between basaltic rock and seawater for the temperature range of $2^{\circ} \mathrm{C}-500^{\circ} \mathrm{C}$ are extrapolated from the experimentally determined equation for clinopyroxene [Wunder et al., 2006] and adjusted according to the observations on hydrothermal fluids [Bray, 2001; Chan et al., 1993] and direct measurement on natural fluid-rock systems and basalt-seawater leaching experiments [Chan et al., 1992, 1993, 1994; James et al., 2003; Seyfried et al., 1998]. Our model calculation used the following fractionation factors: for temperatures of $250^{\circ} \mathrm{C}$ to $500^{\circ} \mathrm{C} \alpha$ varies from 0.994 to 0.998 and for $2^{\circ} \mathrm{C}$ to $200^{\circ} \mathrm{C} \alpha$ ranges between 0.981 and 0.993 .

[38] Modeling results for the evolution of bulk $\mathrm{Li}$ content in the altered rocks during low and high temperature alteration are shown in Figure 7. The calculated results confirm that the $\mathrm{w} / \mathrm{r}$ ratio is the dominant factor controlling the Li concentration of the altered bulk rock. Despite the strongly compatible nature of $\mathrm{Li}$ in the alteration products at low temperatures $\left(\mathrm{K}=200\right.$ at $2^{\circ} \mathrm{C}$ and $\mathrm{K}=120$ at $150^{\circ} \mathrm{C}$ ), the measured Li enrichments in the bulk rock can only occur under high $\mathrm{w} / \mathrm{r}$ ratio conditions (Figure 7a). For seawater as the reacting fluid, to generate the Li enrichment in the final altered rock, the $\mathrm{w} / \mathrm{r}$ ratio has to be greater than 20 at temperatures lower than $\sim 200^{\circ} \mathrm{C}$. Even for a fluid with an elevated $\mathrm{Li}$ content $(8 \mu \mathrm{g} / \mathrm{g}$; e.g., a mixture of upwelling hydrothermal fluids and seawater), a minimum $\mathrm{w} / \mathrm{r}$ ratio of $\sim 10$ is required to reach the Li enrichments (Figure 7a).

[39] At higher temperatures above the upper stability of clay minerals $\left(>200^{\circ} \mathrm{C}\right)$, chlorite or amphiboles becomes the major secondary hydrous minerals in altered basalts. Although these phyllosilicates can potentially accommodate Li in their structures, it has been documented that at elevated temperatures, $\mathrm{Li}$ is leached from the basalt [e.g., Chan et al., 1993; Seyfried et al., 1998]. This is confirmed by the modeling results shown in Figure 7c. Owing to the generally low bulk partition coefficients $(\mathrm{K}=0.15$ to $0.35), \mathrm{Li}$ is uniformly depleted in the bulk rock at any given $\mathrm{w} / \mathrm{r}$ ratios. The degree of depletion rapidly increases with the increase of $\mathrm{w} / \mathrm{r}$ ratio at rock- 

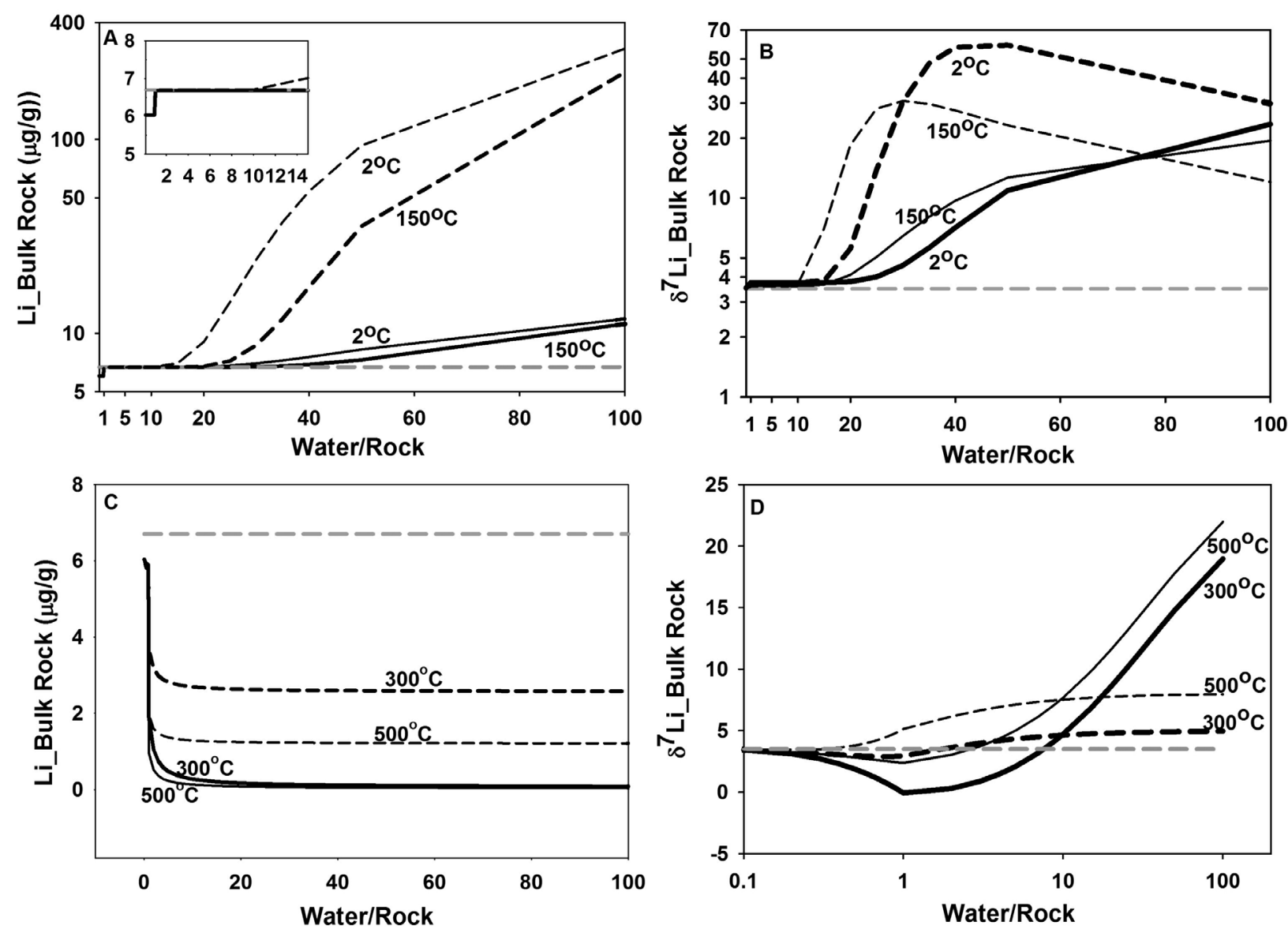

Figure 7. Calculations of changes of bulk rock Li content (ug/g) and isotopic compositions (\%o) during interaction with seawater/fluids with water/rock ratios at (a and b) low and (c and d) high temperatures according to the formulation given by Magenheim et al. [1995]. Black dashed lines are calculated curves for the reaction between fresh basaltic rock (gray dashed line, $\mathrm{Li}=7.2 \mathrm{ug} / \mathrm{g}, \delta^{7} \mathrm{Li}=+3.5 \%$ ) and modified upwelling hydrothermal fluids (mixture of hydrothermal fluids and fresh seawater, $\mathrm{Li}=8 \mathrm{ug} / \mathrm{g}, \delta^{7} \mathrm{Li}=+10 \%$ ) and solid lines are for reaction with fresh seawater $\left(\mathrm{Li}=0.2 \mathrm{ug} / \mathrm{g}, \delta^{7} \mathrm{Li}=+31 \%\right.$ ). Thick represents the starting composition of fresh Reaction temperatures $\left({ }^{\circ} \mathrm{C}\right)$ are marked adjacent to the lines. The modeling parameters used are: $\mathrm{K}=200, \alpha=0.981$ at $2^{\circ} \mathrm{C} ; \mathrm{K}=120, \alpha=0.992$ at $150^{\circ} \mathrm{C} ; \mathrm{K}=0.32, \alpha=0.995$ at $300^{\circ} \mathrm{C}$; and $\mathrm{K}=0.15, \alpha=0.998$ at $500^{\circ} \mathrm{C}$ (see text for the details).

dominated conditions $(\mathrm{w} / \mathrm{r}<1)$ and tend to be stabilized at higher $\mathrm{w} / \mathrm{r}$ ratios (Figure $7 \mathrm{c}$ ). The degree of depletion also increases with the increase of temperature due to the decrease in bulk partition coefficients.

[40] Collectively, modeling results suggest that the observed Li enrichment in the volcanic sections most likely occurred at low temperatures $\left(<200^{\circ} \mathrm{C}\right)$ with localized high $\mathrm{w} / \mathrm{r}$ ratios $(>10)$. In contrast, the general $\mathrm{Li}$ depletion can be best explained by reaction with fluids at high temperatures $\left(>200^{\circ} \mathrm{C}\right)$ beneath the transition zone or at low temperatures $\left(<200^{\circ} \mathrm{C}\right.$ ) but with low $\mathrm{w} / \mathrm{r}$ ratios (less than $\sim 2$, see insect of Figure 7a) in the volcanic section.

[41] The modeling results for $\mathrm{Li}$ isotope variation during alteration (Figures $7 \mathrm{~b}$ and $7 \mathrm{c}$ ) show that the $\delta^{7} \mathrm{Li}$ value of altered bulk rock is also most sensitive to the water/rock ratios. Fluid-rock interaction at low temperatures $\left(<200^{\circ} \mathrm{C}\right)$ will generate uniformly elevated $\delta^{7} \mathrm{Li}$ values in altered rocks, no matter whether the starting fluid is seawater or modified hydrothermal fluid (Figure 7b). However, as shown in Figure 7b, significant elevation of bulk rock $\delta^{7} \mathrm{Li}$ at low temperatures can only occur at conditions with relatively high $\mathrm{w} / \mathrm{r}$ ratios (higher than $\sim 10$ for modified hydrothermal fluid and higher than $\sim 20$ for seawater). Under rock dominated conditions $(\mathrm{w} / \mathrm{r}<1)$ at high temperatures $\left(>200^{\circ} \mathrm{C}\right)$ the bulk rock $\delta^{7} \mathrm{Li}$ values decrease with increasing $\mathrm{w} / \mathrm{r}$ ratios and reaches minimum value at $\mathrm{w} / \mathrm{r}=1$. For $\mathrm{w} / \mathrm{r}>1, \delta^{7} \mathrm{Li}$ increases toward its pristine composition with increasing $\mathrm{w} / \mathrm{r}$ ratio and the bulk rock will eventually obtain an elevated 
$\delta^{7} \mathrm{Li}$ composition (Figure 7d). Compared to seawater $\left(\mathrm{Li}_{\mathrm{SW}}=0.2 \mu \mathrm{g} / \mathrm{g}, \delta^{7} \mathrm{Li} \mathrm{i}_{\mathrm{SW}}=+31 \%\right.$ ) basaltic rock $\left(\mathrm{Li}_{\mathrm{BAS}}=7.2 \mu \mathrm{g} / \mathrm{g}, \delta^{7} \mathrm{Li}_{\mathrm{BAS}}=+3.5 \%\right.$ o $)$ has a similar $\mathrm{Li}$ composition as the proposed modified hydrothermal fluid $\left(\mathrm{Li}_{\mathrm{HT}}=8 \mu \mathrm{g} / \mathrm{g}, \delta^{7} \mathrm{Li}_{\mathrm{HT}}=\right.$ $+10 \%$ ). Thus the formation of altered rocks with depleted $\delta^{7} \mathrm{Li}$ compositions from a modified hydrothermal fluid requires lower temperatures and lower $\mathrm{w} / \mathrm{r}$ ratios compared to unmodified seawater as starting fluid (Figure 7d). Relatively low w/r ratios together with elevated alteration temperatures are therefore required to cause the depletion of ${ }^{7} \mathrm{Li}$ in altered bulk rock (Figure 7d). In contrast, the enrichment of ${ }^{7} \mathrm{Li}$ in altered bulk rock could occur at both low and high temperature conditions, though relatively high $\mathrm{w} / \mathrm{r}$ ratios are required to generate rocks with significantly ${ }^{7} \mathrm{Li}$ enrichment (Figures $7 \mathrm{~b}$ and $7 \mathrm{~d}$ ).

[42] However, seawater $\mathrm{Li}$ (with $\delta^{7} \mathrm{Li}=+31 \%$ ) can also be incorporated through surface adsorption into the clay minerals which are formed during low temperature alteration [Chan et al., 1992; James et al., 2003; Pistiner and Henderson, 2003; Seyfried et al., 1998]. Assuming no isotopic fractionation during adsorption [Pistiner and Henderson, 2003; Vigier et al., 2008], the uptake of seawater Li through adsorption will result in an increase in $\delta^{7} \mathrm{Li}$ in the weathered basalt following a binary mixing law. The lack of positive correlation between Li content and $\delta^{7} \mathrm{Li}$ in rocks from IODP Site 1256 (Figures 2 and 5a) indicates that the surface adsorption process is highly unlikely to be the controlling factor for the observed $\delta^{7} \mathrm{Li}$ variations.

\subsubsection{Seawater Circulation in the Site 1256 Crust}

[43] The downhole variations of $\mathrm{Li}$ content, $\mathrm{Li}$ isotopic and oxygen isotopic compositions of bulk rock samples and modeling presented above indicate in the Site 1256 crust a hitherto unseen alteration sequence and conditions of seawater circulation.

[44] The absence of uniformly elevated $\delta^{7} \mathrm{Li}$ values in the upper low-temperature alteration zone at Site 1256 compared to Hole 504B [Chan et al., 2002] may indicate a combined effect of enhanced upwelling of modified hydrothermal fluid with lighter $\delta^{7} \mathrm{Li}$ values from the deeper sections, rapid sedimentation, and presence of a sealing lava pond.

[45] The seawater penetration in the upper volcanic zone (above $\sim 750 \mathrm{mbsf}$ ) was channeled along flow boundaries, pillow margins, and fractures [Wilson et al., 2003; Teagle et al., 2006; Alt et al., 2010].
Bulk rock $\delta^{7} \mathrm{Li}$ values (Figure $2 \mathrm{~b}$ ) show a wide range although majority cluster tightly around the fresh basalt composition. This is evidence for localized fluid flow at variable $\mathrm{w} / \mathrm{r}$ ratios. The overall enriched $\delta^{18} \mathrm{O}$ values of the basaltic rocks (Figure 2a) suggest that the alteration temperature in this section is generally lower than $250^{\circ} \mathrm{C}$ (Figure 6) [Alt et al., 2010]. According to modeling results, the observed overall Li depletion (Figures $2 \mathrm{c}$ and $4 \mathrm{~b}$ ) indicates that the seawater penetration at low temperature in this section was limited with $\mathrm{w} / \mathrm{r}$ ratios most likely around 2-5 (Figure 7a). The occurrence of altered rocks with high $\mathrm{Li}$ contents together with elevated $\delta^{18} \mathrm{O}$ and $\delta^{7} \mathrm{Li}$ values in the uppermost volcanic section (Figure 2) may suggest that the rocks immediately below the lava pond have been cumulatively exposed to a greater amount of low temperature seawater compared to the deeper volcanic sections. The massive nature of this lava pond likely acted as a barrier to prevent the significant downward penetration of cold seawater. Also the filling of minor basement relief by the flow would have led to a subdued basement topography, which would have reduced off axis fluid flow [Fisher et al., 1994]. The relatively low $\mathrm{w} / \mathrm{r}$ ratio in this zone has also been suggested by secondary mineral study [Alt et al., 2010]. There is much less visible oxidation in Site 1256 lavas formed at superfast spreading rates compared to crust formed at intermediate spreading rates (such as Hole 504B), owing to the restriction of fluid flow due to efficient and rapid sealing of the relatively smooth basement with pelagic sediment accumulation [Alt et al., 2010]. The presence of rocks with low $\delta^{7} \mathrm{Li}$ but high $\delta^{18} \mathrm{O}$ concentration in this volcanic section are possibly interpret by localized reactions between basalt and upwelling hydrothermal fluids at relative high temperatures $\left(\sim 200-250^{\circ} \mathrm{C}\right)$ under various $\mathrm{w} / \mathrm{r}$ ratios. For example, the compositions for sample at $\sim 650 \mathrm{mbsf}$ (206-1256D-57R2-117-127; $16.13 \mu \mathrm{g} / \mathrm{g}$ of $\mathrm{Li},-2.29 \%$ of $\delta^{7} \mathrm{Li}$, and $+8.6 \%$ of $\delta^{18} \mathrm{O}$ ) could be derived from basalt alteration at $200^{\circ} \mathrm{C}$ and $\mathrm{w} / \mathrm{r}=10$ with a modified hydrothermal fluid $(16 \mu \mathrm{g} / \mathrm{g}$ of $\mathrm{Li}$ and $4.3 \%$ of $\delta^{7} \mathrm{Li}$ ). This observation is consistent with the previously described leaking of higher temperature hydrothermal fluid upward across the transition from the underlying dikes $[$ Alt et al., 2010].

[46] The $w / r$ ratios increased rapidly below the depth of $\sim 750 \mathrm{mbsf}$ indicated by the elevated $\delta^{7} \mathrm{Li}$ values, as the significant enrichment of ${ }^{7} \mathrm{Li}$ can only occur at conditions with high $\mathrm{w} / \mathrm{r}$ ratios, especially if at high temperatures (Figure 7d). The majority rocks in the lower volcanic zone, the transition zone and in the sheeted dikes down to $\sim 1300$ mbsf have 
low Li contents, and generally decrease with depth (Figure 2c). According to modeling results (Figure 7) the observed $\mathrm{Li}$ variation trend suggests that the alteration temperature in this zone was generally higher than $200^{\circ} \mathrm{C}$ and increased downward, demanding higher $\mathrm{w} / \mathrm{r}$ to achieve the high $\delta^{7} \mathrm{Li}$ values. This is consistent with the evidence from oxygen isotopes (Figure 2a) and the observed alteration mineralogy [Alt et al., 2010]. This waterdominated situation continues downward into the lower section of the sheeted dike complex at around $1300 \mathrm{mbsf}$. Water/rock ratios then decrease as indicated by the steep gradient from high to low bulk rock $\delta^{7} \mathrm{Li}$ values. The minimum bulk rock $\delta^{7} \mathrm{Li}$ at $\sim 1350$ mbsf most likely reflects the change from water dominant $(\mathrm{w} / \mathrm{r}>1)$ to rock dominant $(\mathrm{w} / \mathrm{r}<1)$ conditions. The amount of penetrated seawater rapidly decreased after entering the plutonic section. The presence of the relatively uniform high $\delta^{7} \mathrm{Li}$ compositions of the basaltic rocks in the lower sheet and massive flows across the transition zone down to the lower sheeted dike complex indicates a fluid dominated pervasive hydrothermal alteration due to the mixing of the down-flowing seawater and up-welling hydrothermal fluids. The high water content in this zone has also been reported by bulk water analysis [Shilobreeva et al., 2011].

[47] Alteration temperatures increase downward from lower than $\sim 150^{\circ} \mathrm{C}$ in the upper volcanic zone to greater than $\sim 250^{\circ} \mathrm{C}$ across the transition zone at $\sim 1100$ mbsf indicated by the transition of $\delta^{18} \mathrm{O}$ values from enrichment to depletion and the occurrence of the overall Li depletion in the basaltic rock. The alteration temperature at the maximum depletion of $\delta^{18} \mathrm{O}, \delta^{7} \mathrm{Li}$ and $\mathrm{Li}$ content at $\sim 1350 \mathrm{mbsf}$ is $\sim 450-500^{\circ} \mathrm{C}$ calculated by oxygen isotopic composition given $\mathrm{w} / \mathrm{r}=1$ depending on the fluid compositions. The alteration temperature continues to increase downward as indicated by the oxygen isotope compositions of secondary minerals [Alt et al., 2010], whereas the increase of $\delta^{18} \mathrm{O}, \delta^{7} \mathrm{Li}$ and $\mathrm{Li}$ content toward their fresh volcanic values indicates the decrease of $w / r$ ratios. The depth of the minimum value of $\delta^{18} \mathrm{O}, \mathrm{Li}$ content, and $\delta^{7} \mathrm{Li}$ at $\sim 1350 \mathrm{mbsf}$ near the top of the granoblastic dikes in the lower dike section marks a transition from water-dominated to rock-dominated conditions.

[48] The above observations may act as an evidence for the presence of effective hydrothermal upwelling from the top of the plutonic rocks. This is the predicted characteristics of hydrothermal system at fast spreading ridges, due to the presence of melt lens underneath the ridges [e.g., Humphris, 1995], which would form a barrier to deeper penetration while it existed. The oceanic crust formed at Site 1256 at a superfast spreading ridge has significantly thinner sheeted dikes $(346 \mathrm{~m})$ and transition zone $(57 \mathrm{~m})$ compared to Hole 504B formed at an intermediate spreading rate (thickness of $1056 \mathrm{~m}$ and $209 \mathrm{~m}$ for sheeted dike and transition zone, respectively [Alt et al., 1993]). The limited thickness of sheeted dike and transition zone may have facilitated the intensive upwelling of the hydrothermal fluid arising from the dike/gabbro contact zone.

\section{Summary and Conclusions}

[49] The combinations of lithium elemental and isotopic compositions with oxygen isotope measurements are useful to constrain the hydrothermal circulation in the oceanic crust.

[50] At ODP Site 1256, low-temperature alteration (below $250^{\circ} \mathrm{C}$ ) dominates above $\sim 750 \mathrm{mbsf}$ in the volcanic section as indicated by $\delta^{18} \mathrm{O}$ values $>6.0 \%$. The penetration of seawater in this region was most likely channelized with generally low w/r ratios. Lithium and oxygen data for the uppermost lavas suggests that they may have been exposed to low-temperature seawater for a longer duration than the deeper volcanic sections prior sealing with sediments. Based on the quantitative modeling, the observed $\mathrm{Li}$ and oxygen isotope signature of the bulk rock in the volcanic section are from hot ( $\left.\sim 200-250^{\circ} \mathrm{C}\right)$, upwelling hydrothermal fluids. These fluids might be the higher-temperature hydrothermal fluids "leaking" upward across the transition from the underlying dikes as proposed by Alt et al. [2010].

[51] The uniformly enriched $\delta^{7} \mathrm{Li}$ values of altered bulk rocks below the depth of $\sim 750$ mbsf suggest that the $\mathrm{w} / \mathrm{r}$ ratios increased rapidly below that depth to form a water dominated situation which continues downward to $\sim 1300 \mathrm{mbsf}$ into the lower section of sheeted dike complex. The steep gradient of bulk rock $\delta^{7} \mathrm{Li}$ values from enrichment to depletion indicates the rapid decrease of the amount of penetrating seawater. The observed maximum depletion of $\delta^{7} \mathrm{Li}$ at $\sim 1350 \mathrm{mbsf}$ marks the transition of the hydrothermal alteration system from seawater dominated $(\mathrm{w} / \mathrm{r}>1)$ to rock dominated $(\mathrm{w} / \mathrm{r}<1)$ with the amount of penetrated seawater rapidly diminishing in the plutonic section.

[52] Alteration temperatures increase downward to greater than $\sim 250^{\circ} \mathrm{C}$ across the transition zone at $\sim 1100 \mathrm{mbsf}$ as shown by the transition of $\delta^{18} \mathrm{O}$ values from enrichment to depletion and the occurrence of low Li content in the basaltic rocks. 
The alteration temperatures at $\sim 1350 \mathrm{mbsf}$ are $450-500^{\circ} \mathrm{C}$ estimated by bulk oxygen isotopic composition assuming $\mathrm{w} / \mathrm{r}$ is close to 1 . The alteration temperature may continue to increase downward into the plutonic section as suggested by oxygen isotopes ratios of secondary minerals [Alt et al., 2010]. Additionally, decreasing $\mathrm{w} / \mathrm{r}$ ratios are also indicated by the increase of $\delta^{18} \mathrm{O}, \delta^{7} \mathrm{Li}$ and $\mathrm{Li}$ content toward fresh volcanic values.

[53] The hitherto unseen isotopic and Li elemental patterns at ODP Site 1256 can be explained by its specific environment of formation. The early emplacement of the massive lava pond covering inflated and sheet flows and the efficient sealing of the relatively smooth basement by rapid sedimentation may have considerably reduced exchanges between seawater and the oceanic crust. Furthermore the small thickness of the sheeted dike and transition zone related to its superfast spreading rate may have facilitated the rapid upwelling of hydrothermal fluids arising from the dike/gabbro contact zone.

\section{Acknowledgments}

[54] This research used samples and/or data provided by the Ocean Drilling Program (ODP) and Integrated Ocean Drilling Program (IODP). ODP and IODP are funded by the U.S. National Science Foundation (NSF) and participating countries under management of Joint Oceanographic Institutions (JOI), Inc. Y.G. and K.M.C. were funded by a grant from the U.S. Science Support Program. F.V. was funded by the Swiss National Science foundation (122759) and a Marie-Curie research grant. We thank William. F. McDonough and Richard Ash from University of Maryland for their support on lithium isotope analysis. The manuscript benefited greatly from both the thorough reviews and the careful, constructive editorial work by L. Derry.

\section{References}

Alt, J. C. (1995), Subseafloor processes in mid-ocean ridge hydrothennal systems, in Seafloor Hydrothermal Systems: Physical, Chemical, Biological, and Geological Interactions, Geophys. Monogr. Ser., vol. 91, edited by S. E. Humphris et al., pp. 85-114, AGU, Washington, D. C., doi:10.1029/ GM091p0085.

Alt, J. C. (2003), Stable isotopic composition of upper oceanic crust formed at a fast spreading ridge, ODP Site 801, Geochem. Geophys. Geosyst., 4(5), 8908, doi:10.1029/2002GC000400.

Alt, J. C., and D. A. H. Teagle (2000), Hydrothermal alteration and fluid fluxes in ophiolites and oceanic crust, in Ophiolites and Oceanic Crust: New Insights From Field Studies and the Ocean Drilling Program, edited by Y. Dilek et al., Spec. Pap. Geol. Soc. Am., 349, 273-282, doi:10.1130/0-81372349-3.273.
Alt, J. C., K. Muehlenbachs, and J. Honnorez (1986), An oxygen isotopic profile through the upper kilometer of the oceanic crust DSDP Hole 504B, Earth Planet. Sci. Lett., 80, 217-229, doi:10.1016/0012-821X(86)90106-8.

Alt, J. C., et al. (1993), Proceedings of the Ocean Drilling Program, Initial Reports, vol. 148, Ocean Drill. Program, College Station, Tex., doi:10.2973/odp.proc.ir.148.1993.

Alt, J. C., D. A. H. Teagle, C. Laverne, D. Vanko, W. Bach, J. Honnorez, K. Becker, M. Ayadi, and P. A. Pezard (1996), Ridge flank alteration of upper ocean crust in the eastern Pacific: A synthesis of results for volcanic rocks of holes 504B and 896A, Proc. Ocean Drill. Program, Sci. Results, $148,435-452$.

Alt, J. C., C. Laverne, R. M. Coggon, D. A. H. Teagle, N. R. Banerjee, S. Morgan, C. E. Smith-Duque, M. Harris, and L. Galli (2010), Subsurface structure of a submarine hydrothermal system in ocean crust formed at the East Pacific Rise, ODP/IODP Site 1256, Geochem. Geophys. Geosyst., 11, Q10010, doi:10.1029/2010GC003144.

Berger, G., J. Schott, and M. Loubet (1987), Fundamental processes controlling the first stage of alteration of a basalt glass by seawater: An experimental study between 200 and $320^{\circ} \mathrm{C}$, Earth Planet. Sci. Lett., 84, 431-445, doi:10.1016/0012821X(87)90008-2.

Berger, G., J. Schott, and C. Guy (1988), Behavior of Li, Rb and Cs during basalt glass and olivine dissolution and chlorite, smectite and zeolite precipitation from seawater: Experimental investigations and modelization between $50^{\circ}$ and $300^{\circ} \mathrm{C}$, Chem Geol., 71, 297-312, doi:10.1016/0009-2541(88)90056-3.

Bickle, M. J., and D. A. H. Teagle (1992), Strontium alteration in the Troodos ophiolite: Implications for fluid fluxes and geochemical transport in mid-ocean ridge hydrothermal systems, Earth Planet. Sci. Lett., 113, 219-237, doi:10.1016/ 0012-821X(92)90221-G.

Böhlke, J. K., J. C. Alt, and K. Muehlenbachs (1984), Oxygen isotope-water relationships in altered deep sea basalts: Low temperature mineralogical controls, Can. J. Earth Sci., 21, 67-77, doi:10.1139/e84-008.

Bouman, C., T. Elliott, and P. Z. Vroon (2004), Lithium inputs to subduction zones, Chem. Geol., 212(1-2), 59-79, doi:10.1016/j.chemgeo.2004.08.004.

Bray, A. (2001), The geochemistry of boron and lithium in mid-ocean ridge hydrothermal vent fluids. $\mathrm{PhD}$ thesis, Univ. of N. H., Durham.

Brenan, J. M., F. J. Ryerson, and H. F. Shaw (1998a), The role of aqueous fluids in the slab-to-mantle transfer of boron, beryllium, and lithium during subduction: Experiments and models, Geochim. Cosmochim. Acta, 62(19-20), 3337-3347, doi:10.1016/S0016-7037(98)00224-5.

Brenan, J. M., E. Neroda, C. C. Lundstrom, H. F. Shaw, F. J. Ryerson, and D. L. Phinney (1998b), Behavior of boron, beryllium, and lithium during melting and crystallization: Constraints from mineral-melt partitioning experiments, Geochim. Cosmochim. Acta, 62(12), 2129-2141, doi:10.1016/S00167037(98)00131-8.

Chan, L. H., J. Edmond, G. Thompson, and K. Gillis (1992), Lithium isotopic composition of submarine basalts: Implications for the lithium cycle in the oceans, Earth Planet. Sci. Lett., 108, 151-160, doi:10.1016/0012-821X(92)90067-6.

Chan, L. H., J. M. Edmond, and G. Thompson (1993), A lithium isotope study of hot-springs and metabasalts from midocean ridge hydrothermal systems, J. Geophys. Res., 98(B6), 9653-9659, doi:10.1029/92JB00840.

Chan, L. H., J. M. Gieskes, C. F. You, and J. M. Edmond (1994), Lithium isotope geochemistry of sediments and 
hydrothermal fluids of the Guaymas basin, Gulf of California, Geochim. Cosmochim. Acta, 58(20), 4443-4454, doi:10.1016/0016-7037(94)90346-8.

Chan, L. H., J. C. Alt, and D. A. H. Teagle (2002), Lithium and lithium isotope profiles through the upper oceanic crust: A study of seawater-basalt exchange at ODP Sites 504B and 896A, Earth Planet. Sci. Lett., 201(1), 187-201, doi:10.1016/ S0012-821X(02)00707-0.

Clayton, R. N., and T. K. Mayeda (1963), The use of bromine pentafluoride in the extraction of oxygen from oxides and silicates for isotopic analysis, Geochim. Cosmochim. Acta, 27, 43-52, doi:10.1016/0016-7037(63)90071-1.

Coumou, D., T. Driesner, S. Geiger, C. A. Heinrich, and S. Matthai (2006), The dynamics of mid-ocean ridge hydrothermal systems: Splitting plumes and fluctuating vent temperatures, Earth Planet. Sci. Lett., 245, 218-231, doi:10.1016/j.epsl.2006.02.044.

Elliott, T., A. Jeffcoate, and C. Bouman (2004), The terrestrial $\mathrm{Li}$ isotope cycle: Light-weight constraints on mantle convection, Earth Planet. Sci. Lett., 220(3-4), 231-245, doi:10.1016/S0012-821X(04)00096-2.

Elliott, T., A. Thomas, A. Jeffcoate, and Y. Niu (2006), Lithium isotope evidence for subduction-enriched mantle in the source of mid-ocean-ridge basalts, Nature, 443, 565-568, doi:10.1038/nature05144.

Farrell, J. W., I. Raffi, T. R. Janecek, D. W. Murray, M. Levitan, K. A. Dadey, K. C. Emeis, M. Lyle, J. A. Flores, and S. Hovan (1995), Late Neogene sedimentation patterns in the eastern equatorial Pacific, Proc. Ocean Drill. Program Sci. Results, 138, 717-756.

Fisher, A. T., K. Becker, and T. N. Narasimhan (1994), Offaxis hydrothermal circulation-Parametric tests of a refined model of processes at deep-sea drilling project ocean drilling program site 504, J. Geophys. Res., 99, 3097-3121, doi:10.1029/93JB02741.

Flesch, G. D., A. R. Anderson, and H. J. Svec (1973), A secondary isotopic standard for ${ }^{6} \mathrm{Li} /{ }^{7} \mathrm{Li}$ determinations, Int. J. Mass Spectrom. Ion Process., 12, 265-272, doi:10.1016/ 0020-7381(73)80043-9.

Fontaine, F. J., and W. S. D. Wilcock (2007), Twodimensional numerical models of open-top hydrothermal convection at high Rayleigh and Nusselt numbers: Implications for mid-ocean ridge hydrothermal circulation, Geochem. Geophys. Geosyst., 8, Q07010, doi:10.1029/2007GC001601.

France, L., B. Ildefonse, and J. Koepke (2009), Interactions between magma and the hydrothermal system in the Oman ophiolite and in IODP Hole 1256D: Fossilization of dynamic melt lens at fast spreading ridges, Geochem. Geophys. Geosyst., 10, Q10O19, doi:10.1029/2009GC002652.

Gao, Y., and J. F. Casey (2011), Lithium isotope composition of ultramafic geological reference materials: JP-1 and DTS-2, Geostand. Geoanal. Res., 36, 75-81.

Gao, Y., J. Hoefs, R. Przybilla, and J. E. Snow (2006), A complete oxygen isotope profile through the lower oceanic crust, ODP Hole 735B, Chem. Geol., 233(3-4), 217-234, doi:10.1016/j.chemgeo.2006.03.005.

Gao, Y., J. Huang, and J. F. Casey (2009), Data report: Trace element geochemistry of oceanic crust formed at a super-fast spreading ridge, Hole 1256D, in Superfast Spreading Rate Crust, Proc. Integr. Ocean Drill. Program, 309/312, doi:10.2204/iodp. proc.309312.202.2009.

German, C., J. Lin, and L. Parson (Eds.) (2004), Mid-Ocean Ridges: Hydrothermal Interactions Between the Lithosphere and Oceans, Geophys. Monogr. Ser., vol. 148, 318 pp., AGU, Washington, D. C., doi:10.1029/GM148.
Gillis, K. M., K. Muehlenbachs, M. Stewart, T. Gleeson, and J. A. Karson (2001), Fluid flow patterns in fast spreading East Pacific Rise crust exposed at Hess Deep, J. Geophys. Res., 106(B11), 26,311-26,329, doi:10.1029/2000JB000038.

Gregory, R. T., and H. P. Taylor (1981), An oxygen isotope profile in a section of Cretaceous oceanic crust, Samail Ophiolite, Oman: Evidence for $\delta^{18} \mathrm{O}$ buffering of the oceans by deep $(>5 \mathrm{~km})$ seawater-hydrothermal circulation at Mid-Ocean Ridges, J. Geophys. Res., 86(B4), 2737-2755, doi:10.1029/JB086iB04p02737.

Harmon, R. S., and J. Hoefs (1995), Oxygen isotope heterogeneity of the mantle deduced from global ${ }^{18} \mathrm{O}$ systematics of basalts from different geotectonic settings, Contrib. Mineral. Petrol., 120(1), 95-114, doi:10.1007/BF00311010.

Heft, K. L., K. M. Gillis, M. A. Pollock, J. A. Karson, and E. M. Klein (2008), Role of upwelling hydrothermal fluids in the development of alteration patterns at fast spreading ridges: Evidence from the sheeted dike complex at Pito Deep, Geochem. Geophys. Geosyst., 9, Q05O07, doi:10.1029/ 2007 GC001926.

Humphris, S. E. (1995), Hydrothermal processes at mid-ocean ridges, Rev. Geophys., 33, supplement, 71-80.

James, R. H., and M. R. Palmer (2000), The lithium isotope composition of international rock standards, Chem. Geol., 166, 319-326, doi:10.1016/S0009-2541(99)00217-X.

James, R. H., D. E. Allen, and W. E. Seyfried (2003), An experimental study of alteration of oceanic crust and terrigenous sediments at moderate temperatures (51 to 350 degrees C): Insights as to chemical processes in near-shore ridgeflank hydrothermal systems, Geochim. Cosmochim. Acta, 67(4), 681-691, doi:10.1016/S0016-7037(02)01113-4.

Jeffcoate, A. B., T. Elliott, A. Thomas, and C. Bouman (2004), Precise, small sample size determinations of lithium isotopic compositions of geological reference materials and modern seawater by MC-ICP-MS, Geostand. Geoanal. Res., 28(1), 161-172, doi:10.1111/j.1751-908X.2004.tb01053.x.

Jeffcoate, A. B., T. Elliott, S. A. Kasemann, D. Ionov, K. Cooper, and R. Brooker (2007), Li isotope fractionation in peridotites and mafic melts, Geochim. Cosmochim. Acta, 71, 202-218, doi:10.1016/j.gca.2006.06.1611.

Jochum, K. P., U. Nohl, K. Herwig, E. Lammel, B. Stoll, and A. W. Hofmann (2005), GeoReM: A new geochemical database for reference materials and isotopic standards, Geostand. Geoanal. Res., 29(3), 333-338, doi:10.1111/ j.1751-908X.2005.tb00904.x.

Koepke, J., D. M. Christie, W. Dziony, F. Holtz, D. Lattard, J. Maclennan, S. Park, B. Scheibner, T. Yamasaki, and S. Yamazaki (2008), Petrography of the dike-gabbro transition at IODP Site 1256 (equatorial Pacific): The evolution of the granoblastic dikes, Geochem. Geophys. Geosyst., 9, Q07O09, doi:10.1029/2008GC001939.

Lehnert, K., Y. Su, C. Langmuir, B. Sarbas, and U. Nohl (2000), A global geochemical database structure for rocks, Geochem. Geophys. Geosyst., 1(5), 1012, doi:10.1029/ 1999GC000026.

Magenheim, A. J., A. J. Spivack, J. C. Alt, G. Bayhurst, L. H. Chan, J. M. Gieskes, and E. Zuleger (1995), Borehole fluid chemistry in Hole 504B, Leg137, Formation water or in situ reaction?, Proc. Ocean Drill. Program Sci. Results, 137/140, 141-152.

Magna, T., U. Wiechert, and A. N. Halliday (2006), New constraints on the lithium isotope compositions of the Moon and terrestrial planets, Earth Planet. Sci. Lett., 243(3-4), 336-353, doi:10.1016/j.epsl.2006.01.005. 
Marschall, H. R., P. A. E. Pogge von Strandmann, H. M. Seitz, T. Elliott, and Y. Niu (2007), The lithium isotopic composition of orogenic eclogites and deep subducted slabs, Earth Planet. Sci. Lett., 262, 563-580, doi:10.1016/ j.eps1.2007.08.005.

Moran, A. E., V. B. Sisson, and W. P. Leeman (1992), Boron depletion during progressive metamorphism: Implications for subduction processes, Earth Planet. Sci. Lett., 111, 331-349, doi:10.1016/0012-821X(92)90188-2.

Moriguti, T., and E. Nakamura (1998), Across-arc variation of Li isotopes in lavas and implications for crust/mantle recycling at subduction zones, Earth Planet. Sci. Lett., 163, 167-174, doi:10.1016/S0012-821X(98)00184-8.

Muehlenbachs, K., and R. N. Clayton (1972), Oxygen isotope studies of fresh and weathered submarine basalts, Can. J. Earth Sci., 9, 172-184, doi:10.1139/e72-014.

Neo, N., S. Yamazaki, and S. Miyashita (2009), Data report: Bulk rock compositions of samples from the IODP Expedition 309/312 sample pool, ODP Hole 1256D, in Superfast Spreading Rate Crust, Proc. Integr. Ocean Drill. Program, 309/312, doi:10.2204/iodp.proc.309312.204.2009.

Nishio, Y., N. Shunichi, J. Yamamoto, H. Sumino, T. Matsumoto, V. S. Prikhodko, and S. Arai (2004), Lithium isotopic systematics of the mantle-derived ultramafic xenoliths: Implications for EM1 origin, Earth Planet. Sci. Lett., 217(3-4), 245-261, doi:10.1016/ S0012-821X(03)00606-X.

Pabst, S., T. Zack, I. P. Savov, T. Ludwig, D. Rost, and E. P. Vicenzi (2011), Evidence for boron incorporation into the serpentine crystal structure, Am. Mineral., 96, 1112-1119, doi:10.2138/am.2011.3709.

Phipps Morgan, J., and Y. J. Chen (1993), The genesis of oceanic crust: Magma injection, hydrothermal circulation, and crustal flow, J. Geophys. Res., 98(B4), 6283-6297, doi:10.1029/ 92JB02650.

Pistiner, J. S., and G. M. Henderson (2003), Lithium-isotope fractionation during continental weathering processes, Earth Planet. Sci. Lett., 214(1-2), 327-339, doi:10.1016/S0012821X(03)00348-0.

Pogge von Strandmann, P. A. E., T. Elliott, H. R. Marschall, C. Coath, Y. J. Lai, A. B. Jeffcoate, and D. A. Ionov (2011), Variations of $\mathrm{Li}$ and $\mathrm{Mg}$ isotope ratios in bulk chondrites and mantle xenoliths, Geochim. Cosmochim. Acta, 75, 5247-5268, doi:10.1016/j.gca.2011.06.026.

Richardson, C. J., J. R. Cann, H. G. Richards, and J. G. Cowan (1987), Metal-depleted root zones of the Troodos ore-forming hydrothermal systems, Cyprus, Earth Planet. Sci. Lett., 84 , 243-253, doi:10.1016/0012-821X(87)90089-6.

Rudnick, R. L., and D. A. Ionov (2007), Lithium elemental and isotopic disequilibrium in minerals from peridotite xenoliths from far-east Russia: Product of recent melt/fluid-rock reaction, Earth Planet. Sci. Lett., 256(1-2), 278-293, doi:10.1016/j.epsl.2007.01.035.

Rudnick, R. L., and E. Nakamura (2004), Preface to "Lithium isotope geochemistry", Chem. Geol., 212(1-2), 1-4, doi:10.1016/ j.chemgeo.2004.08.001.

Rudnick, R. L., P. B. Tomascak, H. B. Njo, and L. R. Gardner (2004), Extreme lithium isotopic fractionation during continental weathering revealed in saprolites from South Carolina, Chem. Geol., 212(1-2), 45-57, doi:10.1016/j.chemgeo. 2004.08.008

Ryan, J. G., and P. R. Kyle (2004), Lithium abundance and lithium isotope variations in mantle sources: Insights from intraplate volcanic rocks from Ross Island and Marie Byrd
Land (Antarctica) and other oceanic islands, Chem. Geol., 212(1-2), 125-142, doi:10.1016/j.chemgeo.2004.08.006.

Ryan, J. G., and C. H. Langmuir (1987), The systematics of lithium abundances in young volcanic rocks, Geochim. Cosmochim. Acta, 51, 1727-1741, doi:10.1016/0016-7037 (87)90351-6.

Schiffman, P., and B. M. Smith (1988), Petrology and oxygen isotope geochemistry of a fossil seawater hydrothermal system within the Solea Graben, northern Troodos ophiolite, Cyprus, J. Geophys. Res., 93, 4612-4624, doi:10.1029/ JB093iB05p04612.

Seyfried, W. E., and J. L. Bischoff (1981), Experimental seawater-basalt interaction at $300^{\circ} \mathrm{C}, 500$ bars, chemical exchange, secondary mineral formation and implications for the transport of heavy metals, Geochim. Cosmochim. Acta, 45(2), 135-147, doi:10.1016/0016-7037(81)90157-5.

Seyfried, W. E., D. R. Janecky, and M. J. Mottl (1984), Alteration of the oceanic crust: Implications for geochemical cycles of lithium and boron, Geochim. Cosmochim. Acta, 48, 557-569, doi:10.1016/0016-7037(84)90284-9.

Seyfried, W. E., X. Chen, and L. H. Chan (1998), Trace element mobility and lithium isotope exchange during hydrothermal alteration of seafloor weathered basalt: An experimental study at 350 degrees C, 500 bars, Geochim. Cosmochim. Acta, 62 (6), 949-960, doi:10.1016/S0016-7037(98)00045-3.

Shilobreeva, S., I. Martinez, V. Busigny, P. Agrinier, and C. Laverne (2011), Insights into $\mathrm{C}$ and $\mathrm{H}$ storage in the altered oceanic crust: Results from ODP/IODP Hole 1256D, Geochim. Cosmochim. Acta, 75, 2237-2255, doi:10.1016/ j.gca.2010.11.027.

Stakes, D. S., and J. R. O’Neil (1982), Mineralogy and stable isotope geochemistry of hydrothermally altered oceanic rocks, Earth Planet. Sci. Lett., 57, 285-304, doi:10.1016/ 0012-821X(82)90151-0.

Stein, C. A., and S. Stein (1994), Constraints on hydrothermal heat flux through the oceanic lithosphere from global heat flow, J. Geophys. Res., 99(B2), 3081-3095, doi:10.1029/ 93JB02222.

Taylor, H. P. (1977), Water/rock interactions and the origin of $\mathrm{H}_{2} \mathrm{O}$ in granitic batholiths, J. Geol. Soc., 133, 509-558, doi:10.1144/gsjgs.133.6.0509.

Teagle, D. A. H., J. C. Alt, W. Bach, A. N. Halliday, and J. Erzinger (1996), Alteration of upper ocean crust in a ridgeflank hydrothermal upflow zone: Mineral, chemical and isotopic constraints from ODP Hole 896A, Proc. Ocean Drill. Program Sci. Results, 148, 119-150.

Teagle, D. A. H., J. C. Alt, S. Umino, S. Miyashita, N. R. Banerjee, D. S. Wilson, and Expedition 309/312 Scientists (2006), Superfast Spreading Rate Crust, Proc. Integr. Ocean Drill. Program, 309/312.

Teagle, D. A. H., B. Ildefonse, P. Blum, and the IODP Expedition 335 Scientists (2012), IODP Expedition 335: Deep sampling in ODP Hole 1256D, Sci. Drill., 13, 28-34.

Tomascak, P. B. (2004), Developments in the understanding and application of lithium isotopes in the earth and planetary science, Rev. Mineral. Geochem., 55, 153-195, doi:10.2138/ gsrmg.55.1.153.

Tomascak, P. B., and C. H. Langmuir (1999), Lithium isotope variability in MORB, Eos Trans. $A G U, 80(46)$, Fall Meet. Suppl., V11E-10.

Tomascak, P. B., E. Widom, L. D. Benton, S. L. Goldstein, and J. G. Ryan (2002), The control of lithium budgets in island arcs, Earth Planet. Sci. Lett., 196(3-4), 227-238, doi:10.1016/S0012-821X(01)00614-8. 
Tomascak, P. B., C. H. Langmuir, P. LeRoux, and S. B. Shirey (2008), Lithium isotopes in global mid-ocean ridge basalts, Geochim. Cosmochim. Acta, 72, 1626-1637, doi:10.1016/ j.gca.2007.12.021.

Tominaga, M., and S. Umino (2010), Lava deposition history in ODP Hole 1256D: Insights from log-based volcano stratigraphy, Geochem. Geophys. Geosyst., 11, Q05003, doi:10.1029/ 2009GC002933.

Tominaga, M., D. A. H. Teagle, J. C. Alt, and S. Umino (2009), Determination of the volcanostratigraphy of oceanic crust formed at superfast spreading ridge: Electrofacies analyses of ODP/IODP Hole 1256D, Geochem. Geophys. Geosyst., 10, Q01003, doi:10.1029/2008GC002143.

Valley, J. W., N. Kitchen, M. J. Kohn, C. R. Niendorf, and M. J. Spicuzza (1995), UWG-2, a garnet standard for oxygen isotope ratios; strategies for high precision and accuracy with laser heating, Geochim. Cosmochim. Acta, 59(24), 5223-5231, doi:10.1016/0016-7037(95)00386-X.

Vigier, N., A. Decarreau, R. Millot, J. Carignan, S. Petit, and C. France-Lanord (2008), Quantifying Li isotope fractionation during smectite formation and implications for the Li cycle, Geochim. Cosmochim. Acta, 72, 780-792, doi:10.1016/j.gca.2007.11.011.

Von Damm, K. L., J. M. Edmond, B. Grant, C. I. Measures, B. Walden, and R. F. Weiss (1985), Chemistry of submarine hydrothermal solutions at $21^{\circ} \mathrm{N}$, East Pacific Rise, Geochim.
Cosmochim. Acta, 49, 2197-2220, doi:10.1016/0016-7037 (85)90222-4.

Wiechert, U., J. Fiebig, R. Przybilla, Y. Xiao, and J. Hoefs (2002), Excimer laser isotope-ratio-monitoring mass spectrometry for in situ oxygen isotope analysis, Chem. Geol., 182(2-4), 179-194, doi:10.1016/S0009-2541(01)00287-X.

Wilson, D. S. (1996), Fastest known spreading on the Miocene Cocos-Pacific plate boundary, Geophys. Res. Lett., 23(21), 3003-3006, doi:10.1029/96GL02893.

Wilson, D. S., et al. (2003), Proceedings of the Ocean Drilling Program, Initial Reports, vol. 206, Ocean Drill. Program, College Station, Tex., doi:10.2973/odp.proc.ir.206.2003.

Wilson, D. S., et al. (2006), Drilling to gabbro in intact ocean crust, Science, 312, 1016-1020, doi:10.1126/science.1126090.

Wunder, B., A. Meixner, R. L. Romer, and W. Heinrich (2006), Temperature-dependent isotopic fractionation of lithium between clinopyroxene and high-pressure hydrous fluids, Contrib. Mineral. Petrol., 151(1), 112-120, doi:10.1007/ s00410-005-0049-0.

Zack, T., P. B. Tomascak, R. L. Rudnick, C. Dalpe, and W. F. McDonough (2003), Extremely light $\mathrm{Li}$ in orogenic eclogites: The role of isotope fractionation during dehydration in subducted oceanic crust, Earth Planet. Sci. Lett., 208(3-4), 279-290, doi:10.1016/S0012-821X(03)00035-9. 